\title{
Effect of Variation in Co-Digestion Ratios of Matooke, Cassava and Sweet Potato Peels on Hydraulic Retention Time, Methane Yield and Its Kinetics
}

\author{
Peter Tumutegyereize $^{1,2}$, Clever Ketlogetswe ${ }^{1}$, Jerekias Gandure ${ }^{1}$, Noble Banadda ${ }^{2}$ \\ ${ }^{1}$ Department of Mechanical Engineering, University of Botswana, Gaborone, Botswana \\ ${ }^{2}$ Department of Agricultural and Biosystems Engineering, Makerere University, Kampala, Uganda \\ Email: ptumutegyereize@caes.mak.ac.ug
}

How to cite this paper: Tumutegyereize, P., Ketlogetswe, C., Gandure, J. and Banadda, N. (2016) Effect of Variation in Co-Digestion Ratios of Matooke, Cassava and Sweet Potato Peels on Hydraulic Retention Time, Methane Yield and Its Kinetics. Journal of Sustainable Bioenergy Systems, 6, 93-115. http://dx.doi.org/10.4236/jsbs.2016.64009

Received: October 28, 2016

Accepted: December 12, 2016

Published: December 15, 2016

Copyright $\odot 2016$ by authors and Scientific Research Publishing Inc. This work is licensed under the Creative Commons Attribution International License (CC BY 4.0).

http://creativecommons.org/licenses/by/4.0/

(c) (i) Open Access

\begin{abstract}
This paper presents the results of batch anaerobic co-digestion of matooke, cassava, and sweet potato peels and vines. These agricultural wastes and others form the biggest portion of household wastes in developing countries. However, they have remained an unexploited resource amidst the ever increasing needs of clean energy and waste disposal challenges. Efforts to use them individually as biogas substrates have been associated with process acidification failure resulting from their fast hydrolysis. The aim of this work was to exploit agricultural wastes is co-digestion among themselves and assess their effect on methane yield and its kinetics, $\mathrm{pH}$ and hydraulic retention time (HRT). Sixteen ratios of Matooke peels (MP), cassava peels (CP) and sweet potato peels (SP) were assessed in duplicate. Methane yield and its kinetics, $\mathrm{pH}$ and HRT demonstrated dependence on the proportion of substrates in the mixture. Depending on the ratio mixture, HRT increased to 15 days compared to less than 5 days for single substrates, hydrolysis rate constant $(\mathrm{k})$ reduced to a range of $0.1-0.3$ $\mathrm{d}^{-1}$ compared to single substrates whose $\mathrm{k}$-values were above $0.5 \mathrm{~d}^{-1}, \mathrm{pH}$ was maintained in the range of $6.38-6.43$ and $\mathrm{CH}_{4}$ yield increased by $15 \%$ - 200\%. Ratios 2:1:0, 2:0:1, 0:1:2, 1:1:1 and 1:1:4 were consistent all through in terms of model fitting, having a positive synergetic effect on HRT, hydrolysis rate constant, lag phase and methane yield. However, more research is needed in maintaining the $\mathrm{pH}$ near the neutral for process stability assurance if household wastes are to be used as standalone substrates for biogas production without being co-substrates with livestock manure.
\end{abstract}

\section{Keywords}

Co-Digestion, Household Wastes, Hydrolysis, Methane Yield, Kinetics 


\section{Introduction}

Clean energy shortage and waste disposal challenges at household level in developing countries are a reality and solutions to them are not likely to be realised in the near future amidst the ever growing population. Biogas a clean and sustainable energy source has been developed to serve in part as a waste management mechanism. Nevertheless, biogas technology dissemination to households has been based on livestock manure, neglecting other household wastes [1], such as matooke peels, cassava peels and sweet potato peels among others, which are widely distributed in most of the developing countries. According to FAOSTAT [2], over $90 \%$ of the developing countries produce at least two of the three crops (banana, cassava and sweet potatoes) from which the peels are produced. These peels form the highest composition of household wastes [3] as well as municipal solid waste (MSW) given that over $60 \%$ of MSW comes from households [4] [5]. Because of the reliance on livestock manure, biogas impact in terms of adoption and use has not been felt since majority of the households do not have livestock. Unlike livestock manure that already contains anaerobes, household wastes and in particular of agricultural origin like matooke peels, cassava peels and sweet potato peels among others are not straightforward substrates to deal with in biogas production. They are liable to acidifying the anaerobic digestion process due to their fast degradability at the hydrolysis stage [6] [7]. In addition, washout of microorganisms is likely to occur due to their short solids retention time/hydraulic retention time associated to their quick degradability [8]. As a result of this, food waste and other household related organic wastes have always been used as co-substrates in most of research and existing working biogas projects [9] [10] [11] [12] [13]. Households however, all they generate is food waste or other agricultural organic wastes like matooke peels, cassava peels and sweet potato peels to mention but a few. Yet, little has been done to understand the performance of household wastes on biogas production process if co-digested between themselves. Co-digestion is said to influence a number of parameters which include among others hydraulic retention time, methane yield and process stability [1]. On the other hand, simple First Order Models that have been widely used in the kinetics of methane production can help in understanding the rates of digestion process [14]. This is not to mention that studies on the kinetics of methane production from the co-digestion of household agricultural wastes amongst themselves were not found in literature. Therefore, the aim of this work was to assess the effect of co-digestion ratio variations of matooke, cassava and sweet potato peels on hydraulic retention time, hydrolysis rate constant and acclimation period as well as the overall methane yield. By doing this, a substrate ratio(s) working in a stable state with controlled hydrolysis rate would be obtained to enable use of household wastes as standalone substrates for biogas production.

\section{Materials and Methods}

\subsection{Sample Preparation and Composition Analysis}

Samples of matooke peels (MP), cassava peels $(\mathrm{CP})$, sweet potato peels $\left(\mathrm{SP}^{\star}\right)$, sweet po- 
tato vines (SV) were secured from the local markets in Kampala. Samples were dried and ground according to Sluiter, Hames [15]. After grinding, SP* and SV were mixed together in a ratio of 2:1 by weight to form SP which was used in combination with MP and CP. The ratio of 2:1 was based on their weights after drying and anticipated protein content. This was to enhance $\mathrm{SP}^{\star}$ with proteins expected from SV [16]. Augmented Simplex Lattice Design (ASLD) in Design expert 7 version was used in coming up with $16 \mathrm{MP}: \mathrm{CP}: \mathrm{SP}$ ratio combinations in addition to $\mathrm{SP}^{\star}$ and $\mathrm{SV}$ standalone samples as presented in Table 1 and Table 2. Total Solids (TS), Volatile Solids (VS) and ash content were determined using Standard Gravimetric Method, APHA-2540D, with an oven set $103^{\circ} \mathrm{C}-105^{\circ} \mathrm{C}$ and muffle furnace at $550^{\circ} \mathrm{C}$ for overnight [17]. Crude fat was extracted from a dried sample using boiling diethyl ether in a Soxhlet Apparatus (AOAC-948.22, 1990). Total and Organic Carbon and Nitrogen in \% were determined using a VARIO Elementar configured for \% C and N. Protein content was estimated by multiply the Nitrogen content by 6.25. Cellulose, hemicellulose and lignin contents were determined by analysis of Neutral Detergent Fibre (NDF), Acid Detergent Fibre (ADF) and Acid Detergent Lignin (ADL) following Van Soest method. That is, cellulose was computed as the difference between ADF and ADL while hemicellulose was calculated as the difference between NDF and ADF. Degradable carbohydrates were estimated by subtracting protein content, fat content and cellulose content from VS. Theoretical methane yield was determined by the composition of organic fraction method as in Equation (1), due to its ability of taking into account the easily biodegradable compounds like carbohydrates, fats and proteins as well as the poorly biodegradable compounds like cellulose [18].

$$
M_{\text {theo }}=415 \times \% \text { carbohydrates }+496 \times \% \text { proteins }+1014 \times \% \text { lipids }
$$

where $M_{\text {theo }}$ is the theoretical methane yield and lipids where equated to fats.

Sample solutions for metal analysis were prepared by dry ashing standard method [19]. Microwave Plasma-Atomic Emission Spectrometry (MP-AES) trade name Agilent 4100 MP-AES (AU13380573) was used for the determination of $\mathrm{Zn}, \mathrm{Co}, \mathrm{Al}, \mathrm{Cu}, \mathrm{Mn}$, $\mathrm{Pb}, \mathrm{Ni}$ and $\mathrm{Fe}$. Atomic Absorption Spectromerty (AAS) was used for Mg determination while $\mathrm{Na}, \mathrm{Ca}$ and $\mathrm{K}$ were determined using the Flame Atomic Emission Spectrometry. On the other hand Sulphur was determined using S-144DR Sulphur Determinator by infrared detection method with oven temperature at $48.38^{\circ} \mathrm{C}$, furnace temperature at $1220.32^{\circ} \mathrm{C}$, furnace set point at $1253.20^{\circ} \mathrm{C}$ and both pump/Oxygen inlet and incoming pressure on.

\subsection{Inoculum and Batch Experiment Description}

The Inoculum was obtained from a $0.5 \mathrm{~m}^{3}$ household biogas digester fed with household organic waste found in Pitsane village, which is located approximately $100 \mathrm{~km}$ South of Gaborone City-Botswana. Inoculum $\mathrm{pH}$ was first measured and was found to be 7.72 before it was kept under ambient temperature for 5 days to maximize digestibility of the remaining VS. Its TS and VS were then determined and found to be $1.52 \%$ and $65.15 \%$ respectively. Inoculum $\mathrm{pH}$ was again measured and a value of 7.45 recorded 
Table 1. Average means for the analyzed macro and micronutrients.

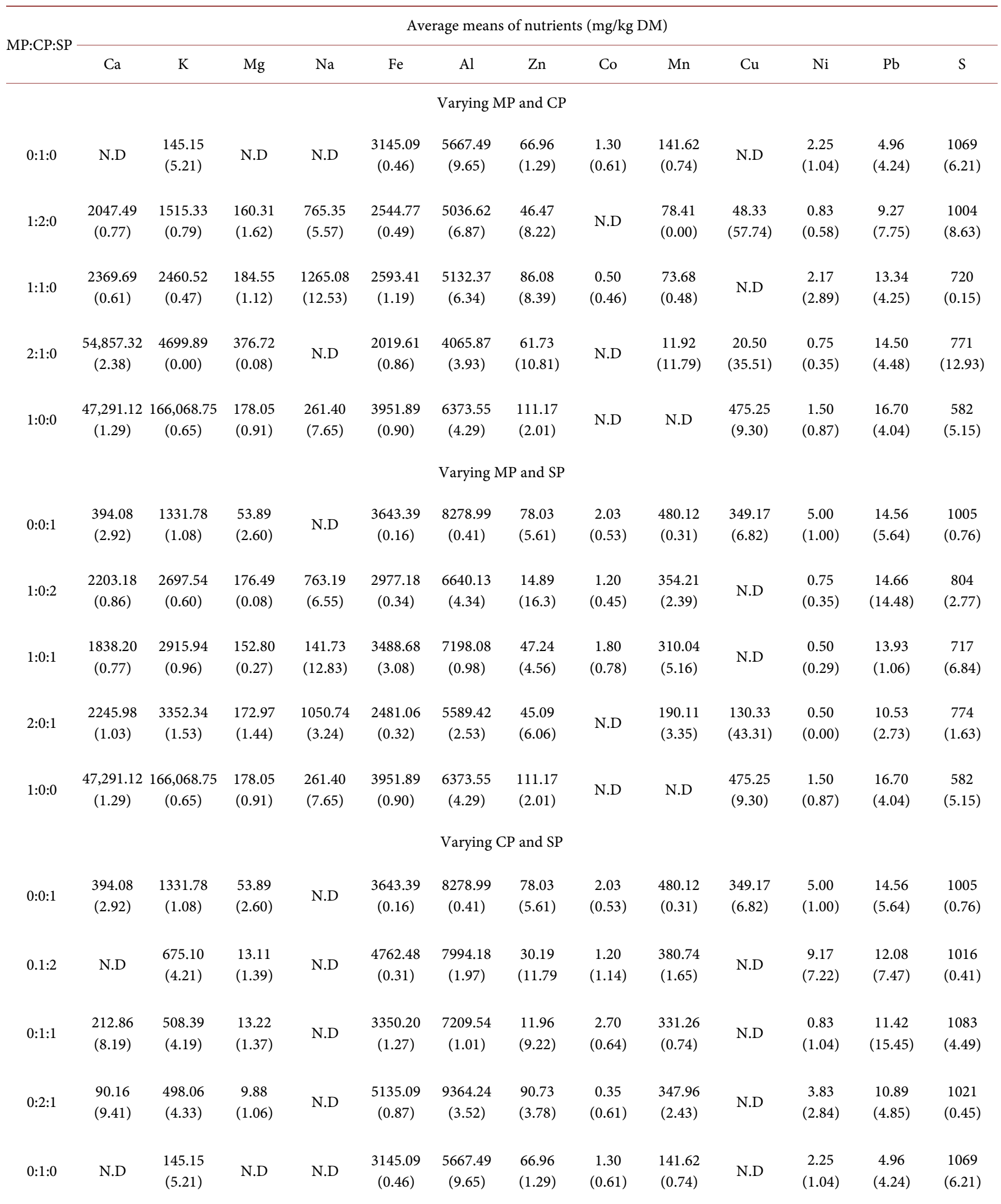




\section{Continued}

\begin{tabular}{|c|c|c|c|c|c|c|c|c|c|c|c|c|c|}
\hline \multicolumn{14}{|c|}{ Varying $\mathrm{MP}, \mathrm{CP}$ and $\mathrm{SP}$} \\
\hline $1: 1: 1$ & $\begin{array}{c}2340.62 \\
(0.40)\end{array}$ & $\begin{array}{c}2307.64 \\
(0.74)\end{array}$ & $\begin{array}{c}176.38 \\
(0.17)\end{array}$ & $\begin{array}{c}957.02 \\
(3.60)\end{array}$ & $\begin{array}{c}3552.22 \\
(1.38)\end{array}$ & $\begin{array}{c}7572.74 \\
(4.16)\end{array}$ & $\begin{array}{c}82.51 \\
(16.46)\end{array}$ & N.D & $\begin{array}{c}360.34 \\
(1.45)\end{array}$ & $\begin{array}{l}50.83 \\
(5.75)\end{array}$ & $\begin{array}{c}3.75 \\
(1.06)\end{array}$ & $\begin{array}{c}12.91 \\
(10.18)\end{array}$ & $\begin{array}{c}952 \\
(3.83)\end{array}$ \\
\hline $1: 1: 4$ & $\begin{array}{c}1989.73 \\
(1.63)\end{array}$ & $\begin{array}{c}1977.21 \\
(0.63)\end{array}$ & $\begin{array}{c}159.98 \\
(0.57)\end{array}$ & $\begin{array}{l}518.07 \\
(10.97)\end{array}$ & $\begin{array}{c}3103.58 \\
(0.31)\end{array}$ & $\begin{array}{c}6473.06 \\
(5.55)\end{array}$ & $\begin{array}{l}46.31 \\
(5.30)\end{array}$ & N.D & $\begin{array}{r}217.09 \\
(0.47)\end{array}$ & N.D & $\begin{array}{c}0.50 \\
(0.29)\end{array}$ & $\begin{array}{c}12.00 \\
(11.24)\end{array}$ & $\begin{array}{l}1003 \\
(4.99)\end{array}$ \\
\hline $1: 4: 1$ & $\begin{array}{c}2366.24 \\
(2.18)\end{array}$ & $\begin{array}{c}1381.88 \\
(0.88)\end{array}$ & $\begin{array}{c}177.39 \\
(0.85)\end{array}$ & $\begin{array}{c}797.24 \\
(5.01)\end{array}$ & $\begin{array}{c}3052.66 \\
(6.49)\end{array}$ & $\begin{array}{c}6074.72 \\
(5.26)\end{array}$ & $\begin{array}{c}72.95 \\
(25.99)\end{array}$ & N.D & $\begin{array}{l}129.95 \\
(18.6)\end{array}$ & $\begin{array}{l}88.75 \\
(7.71)\end{array}$ & $\begin{array}{l}1.00 \\
(00)\end{array}$ & $\begin{array}{l}13.91 \\
(9.85)\end{array}$ & $\begin{array}{l}1117 \\
(0.90)\end{array}$ \\
\hline $4: 1: 1$ & $\begin{array}{c}2066.23 \\
(2.65)\end{array}$ & $\begin{array}{c}2704.98 \\
(0.77)\end{array}$ & $\begin{array}{r}164.59 \\
(0.69)\end{array}$ & $\begin{array}{c}98.99 \\
(77.86)\end{array}$ & $\begin{array}{c}5402.90 \\
(1.50)\end{array}$ & $\begin{array}{c}5362.16 \\
(2.83)\end{array}$ & $\begin{array}{l}122.46 \\
(6.83)\end{array}$ & N.D & $\begin{array}{c}6.76 \\
(2.83)\end{array}$ & $\begin{array}{l}399.17 \\
(29.26)\end{array}$ & N.D & $\begin{array}{c}15.02 \\
(10.58)\end{array}$ & $\begin{array}{c}776 \\
(2.82)\end{array}$ \\
\hline \multicolumn{14}{|c|}{$\mathrm{SV}$ and $\mathrm{SP}^{*}$} \\
\hline SV & $\begin{array}{c}2785.4 \\
(0.51)\end{array}$ & $\begin{array}{c}2549.1 \\
(0.92)\end{array}$ & $\begin{array}{l}226.3 \\
(1.19)\end{array}$ & $\begin{array}{c}184.1 \\
(26.04)\end{array}$ & $\begin{array}{l}5665.3 \\
(0.64)\end{array}$ & $\begin{array}{c}10594.4 \\
(9.39)\end{array}$ & $\begin{array}{l}138.9 \\
(0.25)\end{array}$ & N.D & $\begin{array}{l}372.6 \\
(0.56)\end{array}$ & $\begin{array}{l}485.0 \\
(4.96)\end{array}$ & $\begin{array}{c}7.2 \\
(1.04)\end{array}$ & $\begin{array}{c}15.1 \\
(5.12)\end{array}$ & $\begin{array}{l}1761 \\
(5.5)\end{array}$ \\
\hline $\mathrm{SP}^{*}$ & $\begin{array}{l}447.4 \\
(6.86)\end{array}$ & $\begin{array}{l}2003.4 \\
(1.00)\end{array}$ & $\begin{array}{c}47.8 \\
(3.13)\end{array}$ & $\begin{array}{c}128.8 \\
(23.17)\end{array}$ & $\begin{array}{c}2711.8 \\
(0.31)\end{array}$ & $\begin{array}{l}6002.8 \\
(1.51)\end{array}$ & $\begin{array}{c}68.7 \\
(47.25)\end{array}$ & $\begin{array}{c}2.8 \\
(0.32)\end{array}$ & $\begin{array}{l}678.6 \\
(1.15)\end{array}$ & $\begin{array}{l}216.5 \\
(56.1)\end{array}$ & $\begin{array}{c}3.7 \\
(1.41)\end{array}$ & $\begin{array}{l}18.5 \\
(0.9)\end{array}$ & $\begin{array}{c}611 \\
(2.23)\end{array}$ \\
\hline
\end{tabular}

Table 2. Organic composition in the tested substrate mixtures.

\begin{tabular}{|c|c|c|c|c|c|c|c|c|c|c|c|c|c|c|}
\hline \multicolumn{15}{|c|}{ Varying MP and CP } \\
\hline $0: 1: 0$ & 41.40 & 1.9 & $\begin{array}{l}3.26 \\
(4.0)\end{array}$ & $\begin{array}{c}96.62 \\
(0.1)\end{array}$ & $\begin{array}{c}30.52 \\
(2.3)\end{array}$ & $\begin{array}{c}23.28 \\
(3.3)\end{array}$ & $\begin{array}{c}2.76 \\
(12.2)\end{array}$ & 20.52 & 7.23 & 0.76 & 11.88 & 63.45 & 21.79 & 0.33 \\
\hline $1: 2: 0$ & 41.26 & 1.6 & $\begin{array}{l}4.97 \\
(6.2)\end{array}$ & $\begin{array}{c}95.07 \\
(0.3)\end{array}$ & $\begin{array}{c}30.47 \\
(4.2)\end{array}$ & $\begin{array}{l}9.18 \\
(6.0)\end{array}$ & $\begin{array}{c}3.12 \\
(11.7)\end{array}$ & 6.06 & 21.28 & 1.47 & 10.00 & 77.53 & 25.79 & 0.39 \\
\hline $1: 1: 0$ & 41.62 & 1.3 & $\begin{array}{l}5.89 \\
(4.2)\end{array}$ & $\begin{array}{c}94.34 \\
(0.3)\end{array}$ & $\begin{array}{c}30.95 \\
(1.9)\end{array}$ & $\begin{array}{l}16.76 \\
(13.2)\end{array}$ & $\begin{array}{c}1.50 \\
(22.6)\end{array}$ & 15.26 & 14.20 & 2.15 & 8.13 & 68.80 & 32.01 & 0.35 \\
\hline $1: 0: 0$ & 40.75 & 0.9 & $\begin{array}{l}8.48 \\
(4.1)\end{array}$ & $\begin{array}{c}91.46 \\
(0.3)\end{array}$ & $\begin{array}{c}44.78 \\
(1.9)\end{array}$ & $\begin{array}{c}10.97 \\
(1.2)\end{array}$ & $\begin{array}{c}1.86 \\
(15.3)\end{array}$ & 9.11 & 33.81 & 2.64 & 5.63 & 74.08 & 45.28 & 0.36 \\
\hline \multicolumn{15}{|c|}{ Varying MP and SP } \\
\hline $0: 0: 1$ & 41.11 & 0.9 & $\begin{array}{l}6.41 \\
(0.9)\end{array}$ & $\begin{array}{c}93.42 \\
(0.1)\end{array}$ & $\begin{array}{c}37.26 \\
(4.1)\end{array}$ & $\begin{array}{l}12.43 \\
(10.4)\end{array}$ & $\begin{array}{l}2.68 \\
(5.0)\end{array}$ & 9.75 & 24.83 & 2.23 & 5.63 & 75.81 & 45.67 & 0.37 \\
\hline $1: 0: 2$ & 41.06 & 0.9 & $\begin{array}{l}7.30 \\
(2.8)\end{array}$ & $\begin{array}{c}92.31 \\
(0.1)\end{array}$ & $\begin{array}{c}36.60 \\
(3.7)\end{array}$ & $\begin{array}{c}12.00 \\
(0.9)\end{array}$ & $\begin{array}{l}1.69 \\
(8.0)\end{array}$ & 10.30 & 24.61 & 2.21 & 5.63 & 74.17 & 45.62 & 0.36 \\
\hline
\end{tabular}




\section{Continued}

\begin{tabular}{|c|c|c|c|c|c|c|c|c|c|c|c|c|c|c|}
\hline $1: 0: 1$ & 40.91 & 0.8 & $\begin{array}{l}7.35 \\
(2.3)\end{array}$ & $\begin{array}{c}92.62 \\
(0.2)\end{array}$ & $\begin{array}{c}33.87 \\
(4.7)\end{array}$ & $\begin{array}{l}16.20 \\
(1.4)\end{array}$ & $\begin{array}{l}5.20 \\
(4.9)\end{array}$ & 11.00 & 17.67 & 1.25 & 5.00 & 75.37 & 51.14 & 0.35 \\
\hline $2: 0: 1$ & 41.08 & 0.9 & $\begin{array}{l}8.17 \\
(1.6)\end{array}$ & $\begin{array}{r}91.40 \\
(0.3)\end{array}$ & $\begin{array}{c}39.42 \\
(1.6)\end{array}$ & $\begin{array}{l}15.57 \\
(11.4)\end{array}$ & $\begin{array}{c}2.55 \\
(22.1)\end{array}$ & 13.02 & 23.85 & 2.35 & 5.63 & 70.41 & 45.64 & 0.34 \\
\hline 1:0:0 & 40.75 & 0.9 & $\begin{array}{l}8.48 \\
(4.1)\end{array}$ & $\begin{array}{c}91.46 \\
(0.3)\end{array}$ & $\begin{array}{c}44.78 \\
(1.9)\end{array}$ & $\begin{array}{l}10.97 \\
(1.2)\end{array}$ & $\begin{array}{c}1.86 \\
(15.3)\end{array}$ & 9.11 & 33.81 & 2.64 & 5.63 & 74.08 & 45.28 & 0.36 \\
\hline \multicolumn{15}{|c|}{ Varying $\mathrm{CP}$ and $\mathrm{SP}$} \\
\hline $0: 0: 1$ & 41.11 & 0.9 & $\begin{array}{l}6.41 \\
(0.9)\end{array}$ & $\begin{array}{c}93.42 \\
(0.1)\end{array}$ & $\begin{array}{c}37.26 \\
(4.1)\end{array}$ & $\begin{array}{l}12.43 \\
(10.4)\end{array}$ & $\begin{array}{l}2.68 \\
(5.0)\end{array}$ & 9.75 & 24.83 & 2.23 & 5.63 & 75.81 & 45.67 & 0.37 \\
\hline $0.1: 2$ & 41.05 & 1.1 & $\begin{array}{l}5.47 \\
(1.5)\end{array}$ & $\begin{array}{c}94.30 \\
(0.3)\end{array}$ & $\begin{array}{c}30.93 \\
(3.8)\end{array}$ & $\begin{array}{c}12.33 \\
(3.3)\end{array}$ & $\begin{array}{c}1.63 \\
(14.0)\end{array}$ & 10.69 & 18.60 & 2.31 & 6.88 & 74.42 & 37.32 & 0.37 \\
\hline $0: 1: 1$ & 41.06 & 1.3 & $\begin{array}{l}4.70 \\
(4.3)\end{array}$ & $\begin{array}{c}95.29 \\
(0.2)\end{array}$ & $\begin{array}{c}34.93 \\
(0.6)\end{array}$ & $\begin{array}{c}11.92 \\
(0.1)\end{array}$ & $\begin{array}{c}3.19 \\
(15.7)\end{array}$ & 8.73 & 23.01 & 1.58 & 8.13 & 76.86 & 31.58 & 0.38 \\
\hline $0: 2: 1$ & 41.32 & 1.4 & $\begin{array}{l}4.37 \\
(4.6)\end{array}$ & $\begin{array}{c}95.37 \\
(0.3)\end{array}$ & $\begin{array}{c}33.12 \\
(1.9)\end{array}$ & $\begin{array}{l}11.77 \\
(12.4)\end{array}$ & $\begin{array}{l}2.89 \\
(5.1)\end{array}$ & 8.87 & 21.35 & 1.25 & 8.75 & 76.50 & 29.51 & 0.37 \\
\hline 0:1:0 & 41.40 & 1.9 & $\begin{array}{l}3.26 \\
(4.0)\end{array}$ & $\begin{array}{c}96.62 \\
(0.1)\end{array}$ & $\begin{array}{c}30.52 \\
(2.3)\end{array}$ & $\begin{array}{c}23.28 \\
(3.3)\end{array}$ & $\begin{array}{c}2.76 \\
(12.2)\end{array}$ & 20.52 & 7.23 & 0.76 & 11.88 & 63.45 & 21.79 & 0.33 \\
\hline \multicolumn{15}{|c|}{ Varying $\mathrm{MP}, \mathrm{CP}$ and $\mathrm{SP}$} \\
\hline $1: 1: 1$ & 41.05 & 1.2 & $\begin{array}{l}6.20 \\
(3.5)\end{array}$ & $\begin{array}{c}93.67 \\
(0.3)\end{array}$ & $\begin{array}{c}35.43 \\
(1.5)\end{array}$ & $\begin{array}{c}15.54 \\
(4.6)\end{array}$ & $\begin{array}{l}2.14 \\
(7.4)\end{array}$ & 13.40 & 19.89 & 2.24 & 7.50 & 70.53 & 34.21 & 0.35 \\
\hline $1: 1: 4$ & 42.16 & 1.1 & $\begin{array}{l}6.31 \\
(1.7)\end{array}$ & $\begin{array}{c}93.58 \\
(0.1)\end{array}$ & $\begin{array}{c}36.61 \\
(4.9)\end{array}$ & $\begin{array}{c}13.02 \\
(2.8)\end{array}$ & $\begin{array}{c}2.83 \\
(14.4)\end{array}$ & 10.19 & 23.58 & 2.19 & 6.88 & 74.32 & 38.33 & 0.36 \\
\hline $1: 4: 1$ & 41.32 & 1.5 & $\begin{array}{l}4.60 \\
(0.7)\end{array}$ & $\begin{array}{c}95.14 \\
(0.1)\end{array}$ & $\begin{array}{c}29.54 \\
(6.2)\end{array}$ & $\begin{array}{l}11.42 \\
(4.1)\end{array}$ & $\begin{array}{c}2.76 \\
(11.3)\end{array}$ & 8.66 & 18.11 & 2.00 & 9.38 & 75.10 & 27.54 & 0.38 \\
\hline $4: 1: 1$ & 41.06 & 1.1 & $\begin{array}{l}7.26 \\
(3.3)\end{array}$ & $\begin{array}{c}92.41 \\
(0.3)\end{array}$ & $\begin{array}{c}39.92 \\
(3.3)\end{array}$ & $\begin{array}{c}19.28 \\
(6.6)\end{array}$ & $\begin{array}{c}2.45 \\
(16.9)\end{array}$ & 16.83 & 20.64 & 2.64 & 6.88 & 66.06 & 37.33 & 0.34 \\
\hline \multicolumn{15}{|c|}{$\mathrm{SV}$ and $\mathrm{SP}^{*}$} \\
\hline SV & 42.73 & 1.6 & $\begin{array}{l}9.14 \\
(3.1)\end{array}$ & $\begin{array}{c}90.09 \\
(0.3)\end{array}$ & $\begin{array}{c}39.38 \\
(2.9)\end{array}$ & $\begin{array}{c}33.18 \\
(7.3)\end{array}$ & $\begin{array}{c}5.30 \\
(12.8)\end{array}$ & 27.88 & 6.20 & 1.71 & 10.00 & 50.49 & 26.71 & 0.28 \\
\hline $\mathrm{SP}^{*}$ & 40.57 & 0.5 & $\begin{array}{l}5.15 \\
(1.1)\end{array}$ & $\begin{array}{c}94.75 \\
(0.0)\end{array}$ & $\begin{array}{c}35.19 \\
(9.2)\end{array}$ & $\begin{array}{l}8.63 \\
(3.1)\end{array}$ & $\begin{array}{l}2.69 \\
(3.4)\end{array}$ & 5.94 & 26.56 & 1.12 & 3.13 & 84.57 & 81.15 & 0.38 \\
\hline
\end{tabular}

NB: SV and SP* were mixed to form SP while the ratios stand for MP:CP:SP; Values in brackets represent the coefficients of variation (cv); NDF-nuetrual detergent fibre; ADF-acid detergent fibre; ADL—acid detergent lignin; Cel-Cellulose; Hem-Hemicellulose; Deg-Car-Degradable carbohydrates; $\mathrm{Theo}_{-} \mathrm{CH}_{4}-\mathrm{Theoretical}$ methane yield. 
before its use in batch digesters to ensure that it was in optimum range of $6.1-8.5$ [20]. For all the substrate ratios whose characteristics are presented in Table 1 and Table 2, approximately $0.45 \mathrm{~g}$ of each was weighed in to a $250 \mathrm{ml}$ serum bottle. The $0.45 \mathrm{~g}$ of substrate was based on the VS in the inoculum and in the substrate ratios to give an inoculum to substrate ratio of 2:1. Then $80 \mathrm{ml}$ of inoculum was added followed by $70 \mathrm{ml}$ of clean water to make a working volume of $150 \mathrm{ml}$. The initial $\mathrm{pH}$ value was then measured and recorded as $\mathrm{pH}_{\text {start }}$. This was done in duplicate for each substrate ratio with limited space in the incubator being the limiting factor for more replicates. Two control serum bottles each with $120 \mathrm{ml}$ of inoculum and $30 \mathrm{ml}$ of water only were also prepared. All the bottles with their content were placed in an incubator set at $37^{\circ} \mathrm{C}$ to run for 35 days. A data harvester of Easysense Vision model, equipped with a K-type thermocouple and a pressure sensor was set up to record any temperature fluctuations in the incubator and atmospheric pressure at an interval of 1 hour over the entire 35 days. This was to help during gas normalization to standard temperature and pressure (STP) conditions and to detect, if any, the effect of temperature changes on the batch experiment. After 35 days, $\mathrm{pH}$ was again recorded as $\mathrm{pH}_{\text {end }}$ to determine how stable the anaerobic digestion process in each of the digesters was. Percentage reduction in VS was determined for each of the substrate ratios representing degradability using Equation (2).

$$
\text { Degradability }=\frac{V S_{s}-\left(V S_{d}-V S_{I}\right)}{V S_{s}} \times 100 \%
$$

where, $V S_{s}$ is weight of VS fed into the digesters at the start (g),

$V S_{d}$ is weight of VS remaining after digestion $(\mathrm{g})$,

$V S_{I}$ is weight of VS remaining from the inoculum (g).

\subsection{Biogas and Methane Measurements}

Two separate measurements were performed interchangeably at separate intervals. On the first measurement, the volume of biogas was measured by downward displacement of $\mathrm{NaCl}$ solution to minimize $\mathrm{CO}_{2}$ diffusing/dissolving. The second measurement after an interval of six hours, biogas was passed through $\mathrm{NaOH}$ solution allowing all $\mathrm{CO}_{2}$ to be absorbed. The remaining gas that displaced $\mathrm{NaOH}$ solution was assumed to be $\mathrm{CH}_{4}$ [21]. This interchanging measurement of biogas volume and $\mathrm{CH}_{4}$ volume at different intervals continued until the end of 35 days of batch digestion. Interpolation was done to estimate the amount of biogas at the time $\mathrm{CH}_{4}$ was measured. Dividing $\mathrm{CH}_{4}$ volume measured between any two biogas volume recordings by the estimated biogas volume through interpolation was taken to be the mean fraction/percentage of $\mathrm{CH}_{4}$ content in any three consecutive measurements. This procedure is based on El-Mashad [22], who measured methane content twice a week for the first week and once for the rest of the experiment and interpolated. Once a week, biogas sample was collected using a $5 \mathrm{ml}$ gas-tight syringe for gas chromatograph analysis (GC, model 7890A Agilent Technologies) equipped with a flame ionization detector and a $30 \mathrm{~m} \times 0.53 \mathrm{~mm} \times 40 \mu \mathrm{m}$ fused silica capillary column (HP-PLOT/Q). The carrier gas was Nitrogen flowing at $4 \mathrm{ml} / \mathrm{min}$, 
injection port temperature set at $200^{\circ} \mathrm{C}$, oven temperature at $60^{\circ} \mathrm{C}$ and detector temperature at $200^{\circ} \mathrm{C}$ to ascertain what had been measured by $\mathrm{CO}_{2}$ absorption method. Since both biogas and methane were collected over a liquid, they were normalized to STP conditions as in Equation (3) [23]. To correct for the gas that was generated from the inoculum, Equation (4) was used.

$$
\begin{gathered}
V_{o}=\frac{V_{w} T_{o}\left(P_{a}-P_{w}\right)}{T_{a} P_{o}} \\
V_{o c}=\sum_{t=0}^{i} V_{o(t)}-\frac{\sum_{t=0}^{i} V_{o(t)} \times I_{s}}{I_{c}}
\end{gathered}
$$

where, $V_{o}$ is normalized volume of dry gas $(\mathrm{Nml})$,

$V_{W}$ is wet volume of gas as measured over the liquid $(\mathrm{ml})$,

$P_{a}$ is ambient pressure in the room at the time of gas measurement $(\mathrm{Pa})$,

$P_{W}$ is vapour pressure of water as a function of ambient temperature in the incubator $(\mathrm{Pa})$,

$T_{o}$ is standard temperature $(273 \mathrm{~K})$

$T_{a}$ is ambient temperature in the incubator $(\mathrm{K})$,

$P_{o}$ is standard pressure $(\mathrm{Pa}), V_{o c}$ is the corrected normalized cumulative methane yield $(\mathrm{Nml})$, is the normalized cumulative methane yield inclusive of methane from the inoculum $(\mathrm{Nml})$,

$I_{s}$ is the quantity of inoculum added in the substrate $(\mathrm{ml})$,

$I_{c}$ is the quantity of inoculum in the control $(\mathrm{ml})$,

$t$ is the digestion time (days),

$i$ is the number of days the experiment takes.

\subsection{Kinetic Models}

Three models were selected based on their parameters to predict hydrolysis rate constant and lag phase plus their accuracy in predicting parameters in literature [22] [24] [25]. The Modified Gompertz Model (MGM), Exponential model and the Cone model in Equations (5), (6) and (7) respectively were selected for the kinetics of methane production.

$$
\begin{gathered}
M=P \cdot \exp \left\{-\exp \left[\frac{2.7183 R}{P}(\lambda-t)+1\right]\right\} \\
M=P(1-\exp (-k t)) \\
M=\frac{P}{1+(k t)^{-n}}
\end{gathered}
$$

where, $M$ is cumulative methane production $\left(\mathrm{m}^{3} / \mathrm{kg} \mathrm{VS}\right)$,

$\lambda$ is lag-phase time (days),

$P$ is methane production, potential ( $\left.\mathrm{m}^{3} / \mathrm{kg} \mathrm{VS}\right)$,

$R$ is methane production rate $\left(\mathrm{m}^{3} / \mathrm{kg}\right.$ VS day), 
$t$ is digestion time (days),

$k$ is hydrolysis rate constant $\left(\right.$ day $\left.^{-1}\right)$ and $n$ is a dimensionless shape factor.

\subsection{Data Analysis}

Non-linear regression analysis was used in analysis of the models. Solver tool for optimisation in Excel was used to fit the kinetic models already presented in Equations (5), (6) and (7) onto the experimental data to predict the lag-phase time, hydrolysis rate constant, rate of methane production and methane potential. This was achieved by minimizing the sum of square deviations between the measured cumulative methane and the simulated methane values represented in Equation (8). To determine how well the models fitted the data, coefficients of determination were determined through regression analysis using data analysis tools in Excel. Anova single factor analysis was performed to determine whether there was significant difference between the different substrate ratios in terms of methane content in biogas and methane yield. Where a significant difference was found at $5 \%$ significant level, a post-hoc t-test of two sample assuming equal variances was used to differentiate the substrate ratios that were significantly different from one another.

$$
f(\varepsilon)=\min \sum_{t=0}^{i}\left(V_{o c s(t)}-V_{m(t, \varepsilon)}\right)^{2}
$$

where, $f$ is the objective function,

$\varepsilon$ represents other parameters the models depend upon,

$V_{m}$ is the simulated cumulative methane values.

\section{Results and Discussion}

\subsection{Substrate Composition}

Characteristics of the substrates that were used in the batch experiment are presented in Table 1 and Table 2. The composition of K in MP (1:0:0) was extremely high which agrees with data in literature [26]. However, $K$ composition in CP (0:1:0) and SP (0:0:1) was less than $2500 \mathrm{mg} / \mathrm{kg}$ which is in the acceptable range for anaerobic digestion [27]. Conversely, Co and Mn were not detected in MP while in CP and SP were above the recommended range. On a similar note, $\mathrm{Ca}, \mathrm{Na}, \mathrm{Mg}$ and $\mathrm{Cu}$ were not detected in $\mathrm{CP}$ while in MP and SP they were either low, high or within the acceptable range. Such imbalance of nutrients in standalone substrates is said to be rectified when they are mixed together. For instance Mg was not detected in CP (0:1:0) but when mixed with SP (0:0:1) whose $\mathrm{Mg}$ composition was $52.89 \mathrm{mg} / \mathrm{kg}$, the composition of the mixtures ranged from 9.88 to $13.22 \mathrm{mg} / \mathrm{kg}$. On the other hand, $\mathrm{Na}$ was not detected in $\mathrm{CP}$ and SP and when they were mixed together in different proportions, still it was not detected suggesting that selection of substrates to include in the mixture is very important.

These results show that it would be good to use sweet potato peels $\left(\mathrm{SP}^{\star}\right)$ alone without mixing them with SV due to their low \%cellulose of 5.94 and low lignin (\%ADL) of $2.69 \%$ compared to SV with $27.88 \%$ of cellulose and $5.3 \%$ of lignin. However, SP* 
shows to be low in protein content $(3.13 \%)$ due to its low $\% \mathrm{~N}(0.5)$ leading to high C:N ratio of 81.15 compared to $\mathrm{SV}$. Therefore, mixing $\mathrm{SV}$ and $\mathrm{SP}^{*}$ to form $\mathrm{SP}$, represented by the ratio of 0:0:1, improved the C:N ratio to 45.67 which is near the 20 - 30 range said to be good for anaerobic digestion [28]. Though, [6] says a ratio of C:N ranging from 20 to 50 is acceptable depending on the substrate. Proximate composition results for MP (1:0:0) obtained in this study are comparable to those of Anhwange, Ugye [29] and [30], although they were looking at proximate composition of banana peels from other banana species and varieties. Similarly, proximate composition results for $\mathrm{CP}$ (0:1:0) were comparable to those of Oboh [31], in particular the crude protein and carbohydrates, while crude fibre and fat content compare to results determined by Ofoefule and Uzodinma [32]. It is important to note that even when parameters said to influence proximate composition like differences in cultivars, time of harvest or maturity and location among others, were not considered in the study, the findings are still comparable to other varieties from different areas in different countries. Generally mixing MP, CP and SP showed to balance nutrient composition in the mixtures favourable for anaerobic digestion.

\subsection{Effect of MP:CP:SP Ratio Variation on Methane Yield}

Results of batch digestion tests for the varying proportions of MP, CP and SP are presented in Table 3. Matooke peels (MP) represented by ratio 1:0:0 produced 0.28 $\mathrm{Nm}^{3} \mathrm{CH}_{4} / \mathrm{kg}$ VS. This is comparable to the range of $0.24-0.32 \mathrm{Nm}^{3} \mathrm{CH}_{4} / \mathrm{kg}$ VS reported by previous researchers [33] [34] [35]. Cassava peels (CP) given by ratio 0:1:0 generated $0.18 \mathrm{Nm}^{3} \mathrm{CH}_{4} / \mathrm{kg}$ VS which is less than $0.28 \mathrm{Nm}^{3} \mathrm{CH}_{4} / \mathrm{kg}$ VS reported by Jekayinfa and Scholz [36]. Sweet potato peels $\left(\mathrm{SP}^{\star}\right)$ on the other hand produced $0.32 \mathrm{Nm}^{3} \mathrm{CH}_{4} / \mathrm{kg}$ VS while SV produced $0.13 \mathrm{Nm}^{3} \mathrm{CH}_{4} / \mathrm{kg}$ VS. Methane yields from SP* and SV are more or less similar to what is reported in literature [16]. On the other hand, SP produced 0.14 $\mathrm{Nm}^{3} \mathrm{CH}_{4} / \mathrm{kg}$ VS. Given that SP was a mixture of $\mathrm{SP}^{\star}$ and SV, data in literature to compare it with was not found. On a similar note, the rest of the ratios were not compared with any literature as it could not be found and are therefore discussed with respect to their parent substrates.

Varying MP and CP, showed a significant difference $(\mathrm{P}<0.00)$ in terms of methane yield between the substrate ratios. It is noted that 1:1:0 and 1:2:0 ratios were no better than their parent substrates (0:1:0 and 1:0:0). This suggests that mixing two or more substrates in co-digestion is not a guarantee to achieve higher methane yields than the original/parent materials in the mix. There has to be an optimal ratio. Therefore ratio 2:1:0 that produced $0.32 \mathrm{Nm}^{3} / \mathrm{kg}$ VS of methane, though not significant from 0.28 $\mathrm{Nm}^{3} / \mathrm{kg}$ VS of methane produced from 1:0:0 ratio at 5\% significant level, is said to have improved methane production of MP by $15 \%$ and that of CP by $79 \%$ (Figure 1(a)). Unlike MP and CP, variation of MP and SP showed that SP had a synergetic effect on $\mathrm{MP}$ at 1:0:1 and 2:0:1 ratios. Ratio 1:0:1 produced $0.38 \mathrm{Nm}^{3} / \mathrm{kg}$ VS of methane signifying an increase of $36 \%$ for MP and $177 \%$ for SP while, ratio 2:0:1 produced $0.41 \mathrm{Nm}^{3} / \mathrm{kg}$ VS implying an increase in methane yield of $47 \%$ for MP and 199\% for SP (Figure 1(b)). 
Table 3. Average means of biogas, methane, methane content, $\mathrm{pH}$ and percentage reduction in volatile solids.

\begin{tabular}{|c|c|c|c|c|c|c|}
\hline $\begin{array}{l}\text { Substrate } \\
\text { ratio }\end{array}$ & $\begin{array}{c}\text { Biogas } \\
\left(\mathrm{Nm}^{3} / \mathrm{kg} \mathrm{VS}\right)\end{array}$ & $\begin{array}{c}\mathrm{CH}_{4} \\
\left(\mathrm{Nm}^{3} / \mathrm{kg} \mathrm{VS}\right)\end{array}$ & $\% \mathrm{CH}_{4}$ & $\mathrm{pH}_{\text {start }}$ & $\mathrm{pH}_{\text {end }}$ & $\begin{array}{l}\% \mathrm{VS} \\
\text { reduction }\end{array}$ \\
\hline \multicolumn{7}{|c|}{ Varying MP and CP } \\
\hline $0: 1: 0$ & 0.26 & $0.18^{\mathrm{b}}$ & 50.2 & 7.54 & 6.01 & 64.06 \\
\hline $1: 2: 0$ & 0.21 & $0.10^{c}$ & 51.5 & 7.29 & 6.03 & 63.29 \\
\hline $1: 1: 0$ & 0.38 & $0.21^{\mathrm{b}}$ & 55.1 & 7.67 & 6.26 & 64.95 \\
\hline $2: 1: 0$ & 0.63 & $0.32^{\mathrm{a}}$ & 57.0 & 7.58 & 6.38 & 65.22 \\
\hline 1:0:0 & 0.62 & $0.28^{\mathrm{a}}$ & 50.5 & 7.34 & 6.11 & 66.40 \\
\hline \multicolumn{7}{|c|}{ Varying MP and SP } \\
\hline $0: 0: 1$ & 0.29 & $0.14^{\mathrm{c}}$ & 48.8 & 7.64 & 5.94 & 64.37 \\
\hline $1: 0: 2$ & 0.44 & $0.21^{\mathrm{b}}$ & 48.5 & 7.44 & 6.01 & 62.97 \\
\hline $1: 0: 1$ & 0.79 & $0.38^{\mathrm{a}}$ & 52.9 & 7.23 & 6.41 & 61.73 \\
\hline $2: 0: 1$ & 0.79 & $0.41^{\mathrm{a}}$ & 55.7 & 7.67 & 6.43 & 66.81 \\
\hline $1: 0: 0$ & 0.62 & $0.28^{\mathrm{b}}$ & 50.5 & 7.34 & 6.11 & 66.40 \\
\hline \multicolumn{7}{|c|}{ Varying CP and SP } \\
\hline $0: 0: 1$ & 0.29 & $0.14^{\mathrm{c}}$ & 48.8 & 7.64 & 5.94 & 64.37 \\
\hline $0: 1: 2$ & 0.68 & $0.36^{\mathrm{a}}$ & 56.9 & 7.34 & 6.43 & 66.65 \\
\hline $0: 1: 1$ & 0.58 & $0.34^{\mathrm{a}}$ & 52.9 & 7.77 & 5.86 & 59.05 \\
\hline $0: 2: 1$ & 0.71 & $0.39^{\mathrm{a}}$ & 57.7 & 7.09 & 5.9 & 59.28 \\
\hline $0: 1: 0$ & 0.26 & $0.18^{\mathrm{b}}$ & 50.2 & 7.54 & 6.01 & 64.06 \\
\hline \multicolumn{7}{|c|}{ Varying MP, CP and SP } \\
\hline $1: 1: 1$ & 0.57 & $0.30^{\mathrm{a}}$ & 52.7 & 7.56 & 6.39 & 63.11 \\
\hline $1: 1: 4$ & 0.71 & $0.32^{\mathrm{a}}$ & 54.0 & 7.83 & 6.42 & 61.81 \\
\hline $1: 4: 1$ & 0.31 & $0.14^{c}$ & 53.8 & 7.51 & 5.73 & 63.27 \\
\hline $4: 1: 1$ & 0.37 & $0.16^{\mathrm{b}}$ & 51.7 & 7.21 & 7.97 & 64.63 \\
\hline \multicolumn{7}{|c|}{$\mathrm{SV}$ and $\mathrm{SP}^{\star}$} \\
\hline SV & 0.29 & $0.13^{c}$ & 54.5 & 7.91 & 7.37 & 61.75 \\
\hline $\mathrm{SP}^{*}$ & 0.70 & $0.32^{\mathrm{a}}$ & 53.4 & 7.48 & 6.31 & 67.14 \\
\hline
\end{tabular}

NB: 0:0:1 ratio is a mixture of sweet potato peels $\left(\mathrm{SP}^{*}\right)$ and vines (SV); $\mathrm{CH}_{4}$ values having the same superscript letter are not significantly different. 

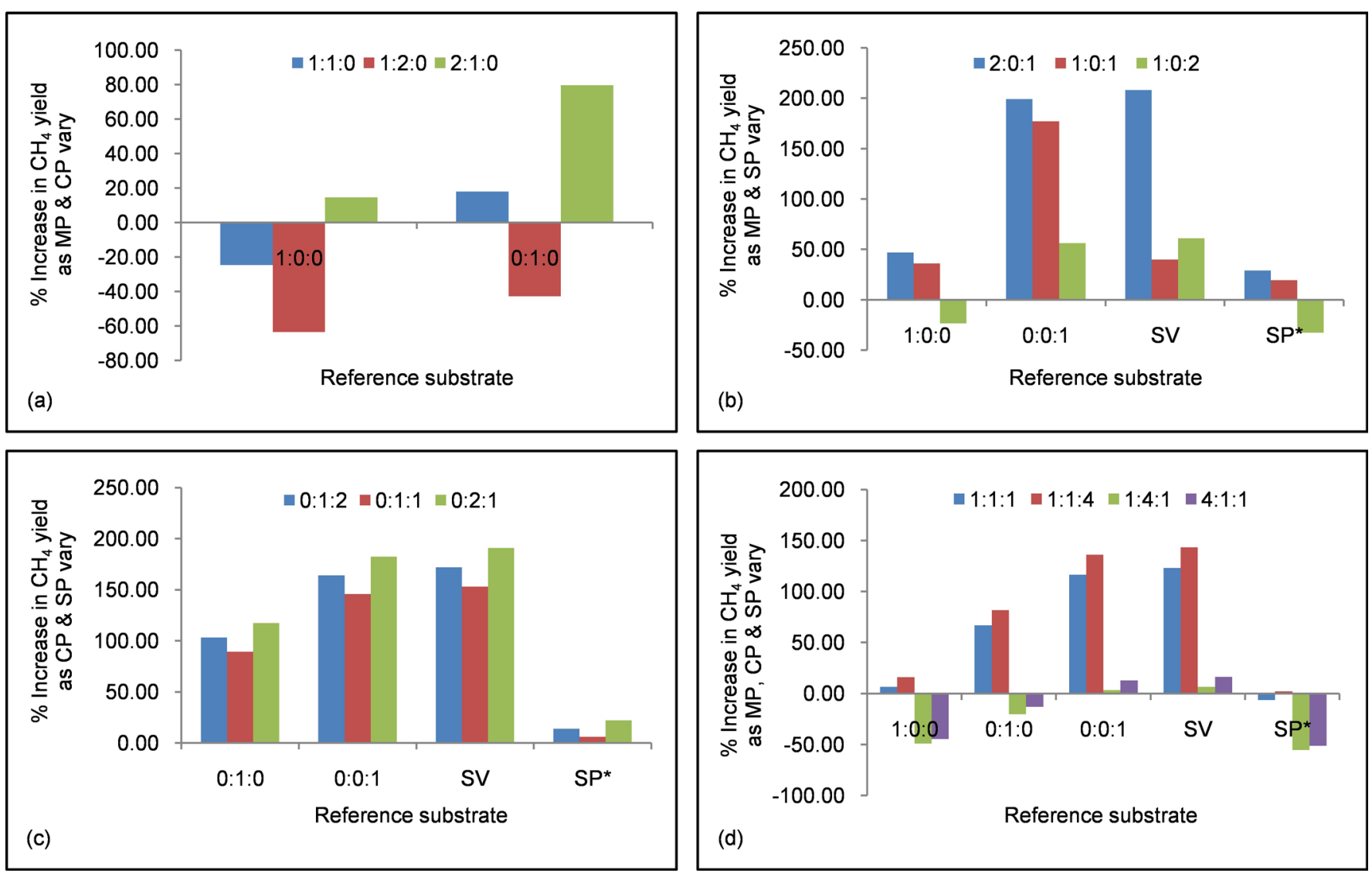

Figure 1. Synergetic effect (\%) on methane yield with respect to the parent substrates (MP, CP, SP, SV and SP*) as MP:CP:SP ratio varies. NB: Ratios 2:1:0, 2:0:1, 1:0:1, 0:1:2, 0:1:1, 0:2:1, 1:1:1 and 1:1:4 had positive synergies to the parent substrates.

Again it can be seen that ratio 1:0:2 produced $0.21 \mathrm{Nm}^{3} / \mathrm{kg}$ VS of methane which is $23 \%$ less compared to $0.28 \mathrm{Nm}^{3} / \mathrm{kg}$ VS from MP (1:0:0). Since SP was a combination of SV and SP*, Figure 1(b) shows that methane yield increased by over $200 \%$ for SV and $29 \%$ for $\mathrm{SP}^{\star}$ at 2:0:1 ratio and $40 \%$ for SV and $19 \%$ for $\mathrm{SP}^{\star}$ at 1:0:1 ratio. On the other hand, varying $\mathrm{CP}$ and SP had a synergetic effect on each other. That is to say, all the ratios 0:1:1, 0:1:2 and 0:2:1 produced methane that was significant $(\mathrm{P}<0.00)$ compared to their parent substrates. This can generally be seen clearly in Figure 1(c) which shows great increase of over $100 \%$ in methane yield for the three ratios referenced to their parent substrates. Similarly, Figure 1(d) shows that when MP, CP and SP were varied at four distinct ratios $(1: 1: 1,1: 1: 4,1: 4: 1 \& 4: 1: 1)$, only 1:1:1 and 1:1:4 ratios had positive synergies on methane yield for all the three parent substrates. Ratio 1:1:4 showed to have the highest synergies on methane yield of $16 \%, 81 \%, 136 \%, 143 \%$ and $2 \%$ for MP, $\mathrm{CP}, \mathrm{SP}, \mathrm{SV}$ and $\mathrm{SP}^{*}$ respectively. Average methane content $\left(\% \mathrm{CH}_{4}\right)$ in biogas for all the tested substrate ratios was in the range of $48.5 \%-57.7 \%$ which agrees with previous studies [35] [37].

It is important to note that no buffer for $\mathrm{pH}$ control like the common $\mathrm{Na}_{2} \mathrm{CO}_{3}$ was used in this batch co-digestion experiment. This was intended to assess whether the three substrates in question would have a buffering effect towards one another for $\mathrm{pH}$ 
control. Although it is generally seen in Table 3 that $\mathrm{pH}$ had decreased from $\mathrm{pH}_{\text {start }}$ to $\mathrm{pH}_{\text {end }}$ by the end of the experiment, it is worthy to note that $\mathrm{pH}_{\text {end }}$ values for a number of ratios were still within the $\mathrm{pH}$ range of 6.1 - 8.3 said to favour anaerobic digestion [20]. This is not to mention that with the exception of ratio $0: 1: 2, \mathrm{pH}_{\text {end }}$ values for the other ratios where $\mathrm{CP}$ and $\mathrm{SP}$ were varied as well as ratio 1:4:1 were below the acceptable $\mathrm{pH}$ range. In addition, ratios where $\mathrm{CP}$ or $\mathrm{SP}$ was more than $\mathrm{MP}, \mathrm{pH}_{\text {end }}$ values were at the lower margin of the range with the exception of ratio 1:1:4. On a similar note, $\mathrm{pH}_{\text {end }}$ values for the parent substrates represented by ratios 1:0:0, 0:1:0 and 0:0:1 were also on the lower margin of the required $\mathrm{pH}$ range. Therefore, using at least two of the three substrates in biogas production requires an understanding of the proportions of the different substrates in the mixture that would maintain $\mathrm{pH}$ in the range favourable for microorganisms. In this case ratios $0: 1: 2,1: 0: 1,1: 1: 0,1: 1: 1,1: 1: 4,2: 0: 1,2: 1: 0$ and 4:1:1 showed to have maintained a better $\mathrm{pH}_{\text {end }}$. However, in terms of methane yield ratios 1:1:0 and 4:1:1 performed poorly. Ratios having CP more than either MP or SP also performed poorly in terms of methane yield except ratio 0:2:1, though its $\mathrm{pH}_{\text {end }}$ value was 5.9. This is out of the acceptable $6.1-8.3 \mathrm{pH}$ range. This poor performance of the ratios having more $\mathrm{CP}$ than $\mathrm{MP}$ or SP can be partly explained by the kinetics of methane production presented in section 3.3. However, Panichnumsin, Nopharatana [38], also noted a decrease in methane production when CP exceeded $60 \%$ in co-digestion of $\mathrm{CP}$ and pig manure.

Unlike methane yield that showed significant difference at $5 \%$ significant level between the different substrates ratios, there was no difference for volatile solids reduction, which is unexpected. Given the complexity of anaerobic co-digestion, other internal reactions utilizing VS without necessarily converting it to biogas could have taken place. This unusual characteristic of VS reduction not marching with methane yield was noted by Bardiya, Somayaji [37] when dealing with biomethanation of banana peels. A VS reduction of $31 \%$ with methane yield of $219 \mathrm{l} / \mathrm{kg}$ TS at HRT of 40 days and VS reduction of $41 \%$ with methane yield of $188 \mathrm{l} / \mathrm{kg}$ TS at HRT of 25 days were obtained. This is unexpected because one would expect VS reduction to increase with HRT as well as methane yield. However, VS reduction percentages obtained in this study are comparable to values of other materials of plant origin found in literature [38] [39] [40].

\subsection{Estimation of Kinetics of Methane Production Parameters}

Figure 2, Figure 3 and Figure 4 show MGM, exponential and Cone models respectively fitted onto experimental methane production data for the respective MP:CP:SP ratios. Table 4 presents the kinetic parameters estimated by the respective models. To guide the discussion, any model whose coefficient of determination $\left(R^{2}\right)$ was 0.99 and above (explaining 99\% and above of the variations in experimental data) was considered to have adequately fitted the data. Otherwise it was taken not to have adequately fitted the data given that hydrolysis rate of any substrate can be represented by its methane production only when there is no accumulation of intermediary compounds, 

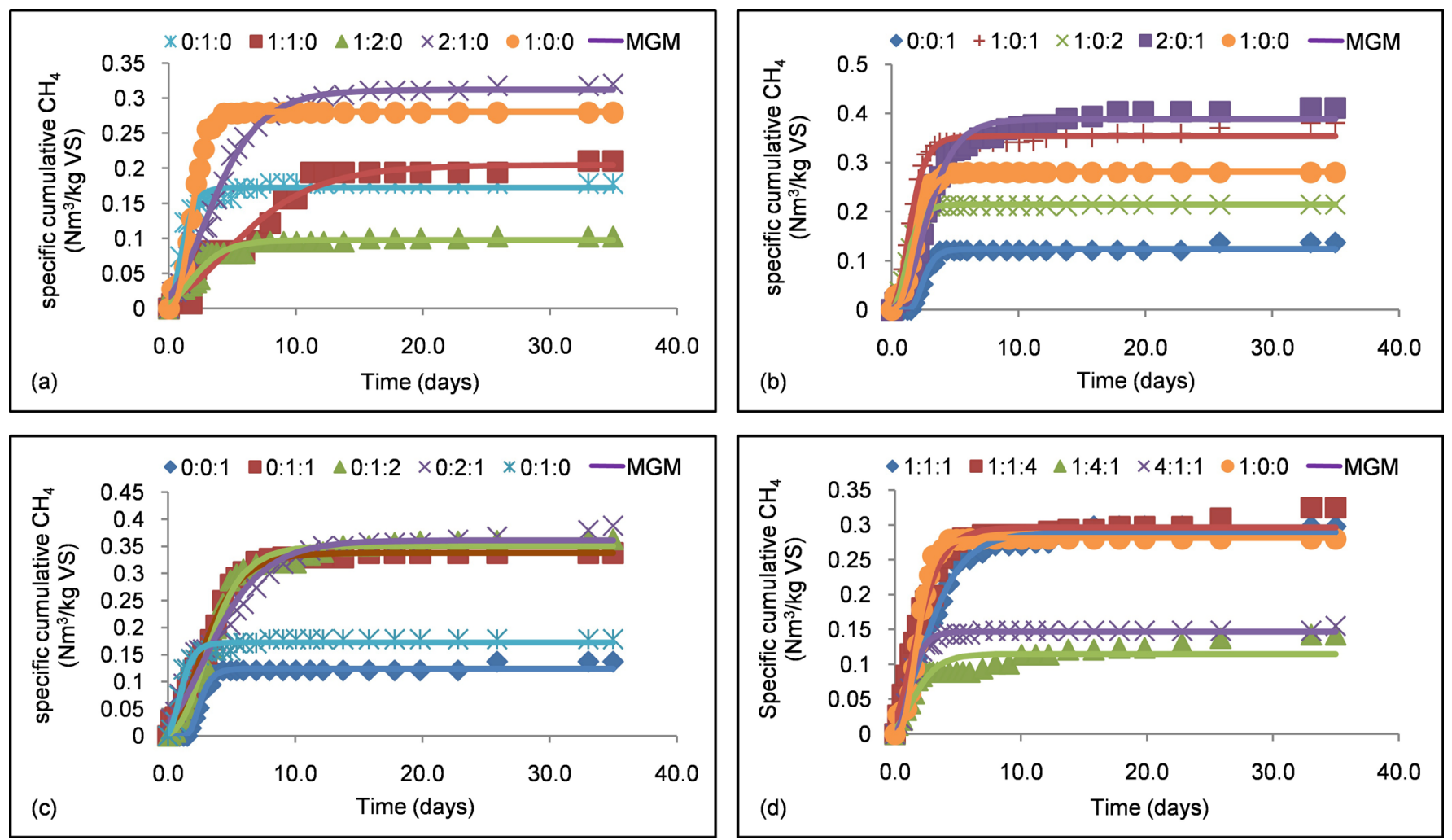

Figure 2. Modified gompertz model fitted onto methane yield from the ratios of matooke, cassava and sweet potato peels.
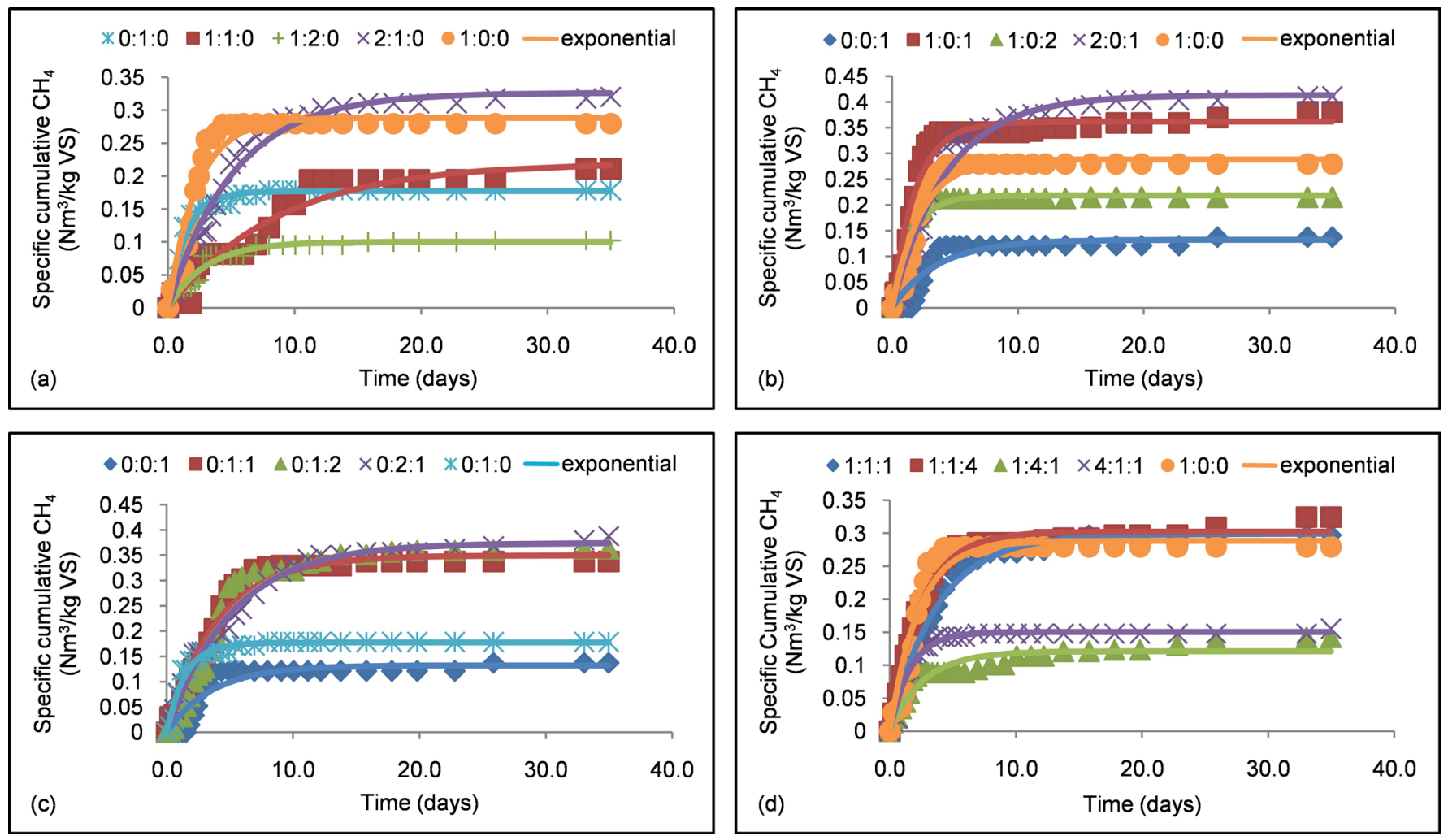

Figure 3. Exponential model fitted onto methane yield from the ratios of matooke, cassava and sweet potato peels. 

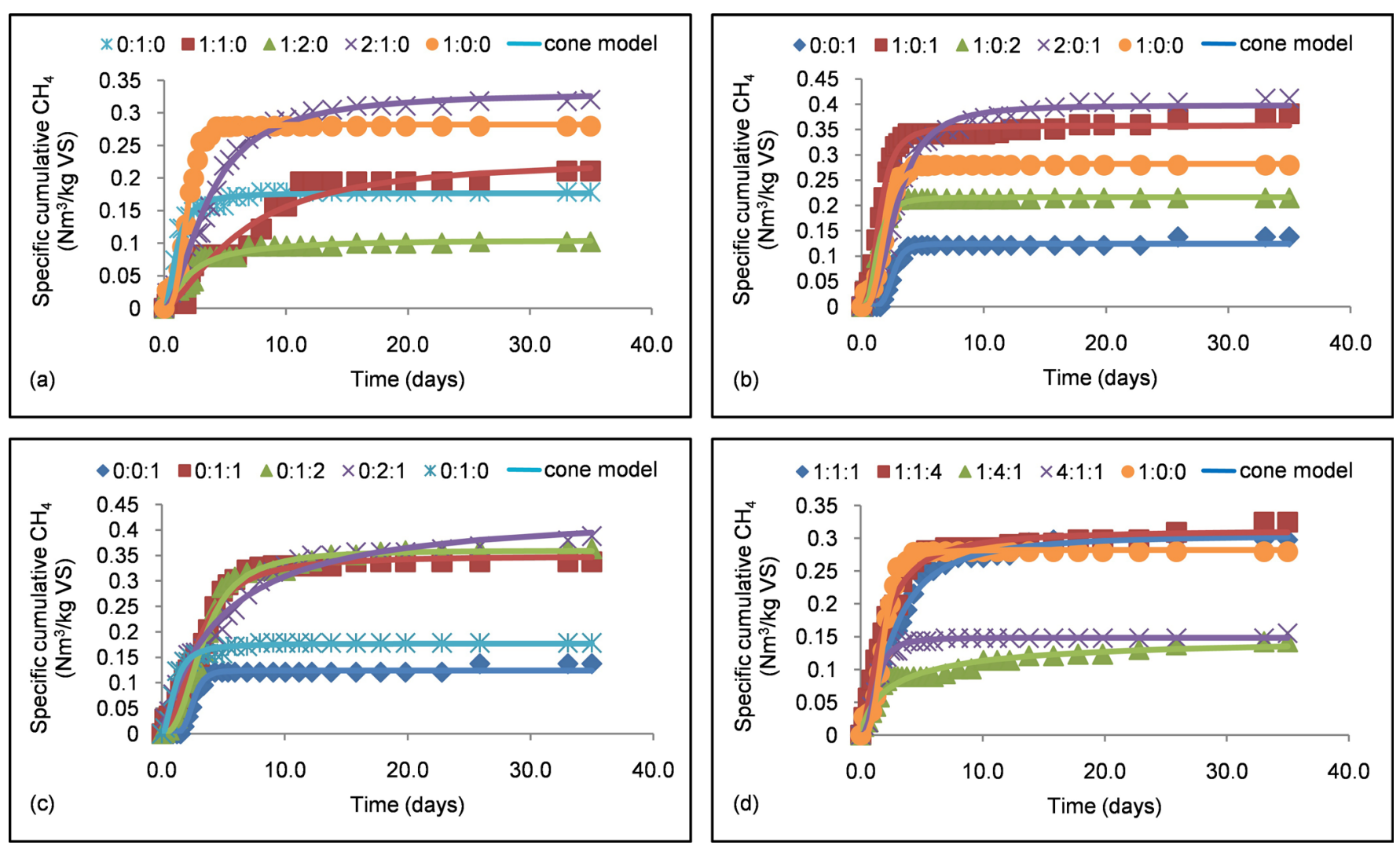

Figure 4. Cone model fitted onto methane yield from the ratios of matooke, cassava and sweet potato peels.

according to Veeken and Hamelers [24]. Therefore, any MP:CP:SP ratio whose variations in methane production data were not adequately explained by the models $\left(\mathrm{R}^{2}<\right.$ 0.99) was assumed to have had inhibition from intermediary compounds.

Considering the parent substrate $\mathrm{MP}, \mathrm{CP}, \mathrm{SP}, \mathrm{SP}^{\star}$ and $\mathrm{SV}$ ) alone, it can be generally said that MGM and Cone model adequately fitted methane production from MP and SP with $99 \%$ of the variations explained by the models. However, considering their hydrolysis rate constants (k), MP, $\mathrm{CP}$ and $\mathrm{SP}^{\star}$ had relatively high k-values of $0.547,0.96$ and 0.912 respectively compared to SV and SP. For SV having a low k-value of 0.254 could be attributed to its high content of cellulose compared to the other parent substrates (Table 2 Section 3.1). On the other hand, the relatively low k-value for SP of 0.394 could be due to the synergetic effect resulting from mixing SV and SP*. The high $\mathrm{k}$-values for $\mathrm{MP}, \mathrm{CP}$ and $\mathrm{SP}^{\star}$ affirm to very fast hydrolysis processes during digestion which may lead to accumulation of intermediary products beyond which the methanogenesis process can handle, thus resulting into process instability. This is in agreement with other researchers [6] [7]. It is therefore hoped that using them in mixed mode would reduce on their respective hydrolysis rates thus stabilizing the digestion process.

When MP and CP were varied, only methane production from ratio 2:1:0 was adequately fitted by the MGM and Cone model. The hydrolysis rate constant $\mathrm{k}$ for 2:1:0 ratio estimated by the Cone model was reduced to $0.277 \mathrm{~d}^{-1}$ which is in the range of 0.005 - $0.47 \mathrm{~d}^{-1}$ reported by Mata-Alvarez, Macé [41]. This indicates that there is a synergetic 
Table 4. Predicted parameters of the models and their coefficients of determination.

\begin{tabular}{|c|c|c|c|c|c|c|c|c|c|c|c|c|c|c|}
\hline Substrate & $P$ & $R$ & $\lambda$ & $R^{2}$ & $\operatorname{Adj} R^{2}$ & $P$ & $k$ & $R^{2}$ & $\operatorname{Adj} R^{2}$ & $P$ & $k$ & $n$ & $R^{2}$ & $\operatorname{Adj} R^{2}$ \\
\hline \multicolumn{15}{|c|}{ Varying MP and CP } \\
\hline $0: 1: 0$ & 0.172 & 0.098 & 0.188 & 0.969 & 0.968 & 0.177 & 0.692 & 0.967 & 0.966 & 0.177 & 0.960 & 2.081 & 0.984 & 0.984 \\
\hline $1: 1: 0$ & 0.205 & 0.019 & 0.207 & 0.951 & 0.95 & 0.220 & 0.115 & 0.95 & 0.948 & 0.230 & 0.163 & 1.520 & 0.952 & 0.950 \\
\hline $2: 1: 0$ & 0.312 & 0.046 & 0.175 & 0.995 & 0.995 & 0.327 & 0.193 & 0.986 & 0.986 & 0.332 & 0.277 & 1.756 & 0.991 & 0.991 \\
\hline $1: 0: 0$ & 0.281 & 0.128 & 0.731 & 0.995 & 0.995 & 0.289 & 0.442 & 0.94 & 0.938 & 0.282 & 0.547 & 3.516 & 0.994 & 0.994 \\
\hline $1: 0: 2$ & 0.215 & 0.118 & 0.379 & 0.996 & 0.996 & 0.218 & 0.645 & 0.958 & 0.957 & 0.216 & 0.779 & 2.987 & 0.992 & 0.992 \\
\hline $1: 0: 1$ & 0.354 & 0.163 & 0.396 & 0.991 & 0.99 & 0.362 & 0.535 & 0.961 & 0.959 & 0.358 & 0.684 & 2.698 & 0.990 & 0.989 \\
\hline $2: 0: 1$ & 0.388 & 0.098 & 0.878 & 0.99 & 0.99 & 0.414 & 0.232 & 0.964 & 0.963 & 0.398 & 0.350 & 2.581 & 0.995 & 0.995 \\
\hline $1: 0: 0$ & 0.281 & 0.128 & 0.731 & 0.995 & 0.995 & 0.289 & 0.442 & 0.94 & 0.938 & 0.282 & 0.547 & 3.516 & 0.994 & 0.994 \\
\hline \multicolumn{15}{|c|}{ Varying CP and SP } \\
\hline $0: 0: 1$ & 0.124 & 0.076 & 1.705 & 0.99 & 0.989 & 0.132 & 0.278 & 0.872 & 0.868 & 0.124 & 0.394 & 6.079 & 0.990 & 0.989 \\
\hline $0: 1: 0$ & 0.172 & 0.098 & 0.188 & 0.969 & 0.968 & 0.177 & 0.692 & 0.967 & 0.966 & 0.177 & 0.960 & 2.081 & 0.984 & 0.984 \\
\hline \multicolumn{15}{|c|}{ Varying MP, CP and SP } \\
\hline $1: 1: 1$ & 0.289 & 0.056 & 0.042 & 0.992 & 0.991 & 0.299 & 0.268 & 0.991 & 0.991 & 0.306 & 0.380 & 1.690 & 0.995 & 0.995 \\
\hline $1: 1: 4$ & 0.296 & 0.081 & 0 & 0.984 & 0.984 & 0.302 & 0.408 & 0.988 & 0.987 & 0.312 & 0.570 & 1.574 & 0.990 & 0.989 \\
\hline $1: 4: 1$ & 0.115 & 0.034 & 0 & 0.858 & 0.853 & 0.121 & 0.378 & 0.902 & 0.898 & 0.152 & 0.372 & 0.815 & 0.952 & 0.950 \\
\hline $4: 1: 1$ & 0.147 & 0.076 & 0.307 & 0.991 & 0.991 & 0.150 & 0.617 & 0.969 & 0.968 & 0.149 & 0.798 & 2.608 & 0.994 & 0.993 \\
\hline \multicolumn{15}{|c|}{$\mathrm{SV}$ and $\mathrm{SP}^{*}$} \\
\hline SV & 0.098 & 0.027 & 0 & 0.755 & 0.746 & 0.101 & 0.390 & 0.832 & 0.826 & 0.144 & 0.254 & 0.636 & 0.897 & 0.893 \\
\hline $\mathrm{SP}^{\star}$ & 0.291 & 0.133 & 0.064 & 0.98 & 0.98 & 0.295 & 0.683 & 0.981 & 0.981 & 0.298 & 0.912 & 1.906 & 0.983 & 0.982 \\
\hline
\end{tabular}

NB: 0:0:1 ratio is a mixture of sweet potato peels $\left(\mathrm{SP}^{*}\right)$ and vines (SV), $\mathrm{M}$ is cumulative methane production $\left(\mathrm{m}^{3} / \mathrm{kg} \mathrm{VS}\right), \lambda$ is lag-phase time (days), $\mathrm{P}$ is methane production potential $\left(\mathrm{m}^{3} / \mathrm{kg}\right.$ VS), $\mathrm{R}$ is methane production rate $\left(\mathrm{m}^{3} / \mathrm{kg}\right.$ VS day), $\mathrm{t}$ is digestion time (days), $\mathrm{k}$ is hydrolysis rate constant $\left(\right.$ day $\left.{ }^{-1}\right)$ and $\mathrm{n}$ is a dimensionless shape factor. 
effect on hydrolysis rate when two parts of MP are mixed with one part of CP for anaerobic digestion. Similarly, there was a synergetic effect on lag phase $(\lambda)$ for ratio 2:1:0 as it was reduced to 0.175 days compared to 0.731 and 0.188 days for MP and CP respectively. Although ratios 1:2:0 and 1:1:0 had also $\mathrm{k}$ and $\lambda$ values synergised, none of the models fitted them, an indication of inhibition evidenced by their $\mathrm{pH}_{\text {end }}$ in Table 3 .

However, when MP and SP were varied, all the three ratios (1:0:2, 1:0:1, 2:0:1) were adequately fitted by both MGM and Cone model. That is MGM and Cone model were able to explain over $99 \%$ of the variations in their methane production. Nonetheless, only ratio 2:0:1 had both its hydrolysis rate constant $\mathrm{k}$ and lag phase $\lambda$ synergised to $0.35 \mathrm{~d}^{-1}$ and 0.878 days respectively compared to their parent substrates. The remaining ratios 1:0:2 and 1:0:1 had only their lag phase synergised to 0.379 and 0.396 days. The hydrolysis rate constants for ratios 1:0:2 and 1:0:1 of 0.779 and $0.684 \mathrm{~d}^{-1}$ respectively were found to be higher compared to their parent substrates. These high hydrolysis rate constants $\mathrm{k}$ of 0.779 and $0.684 \mathrm{~d}^{-1}$ can be as a result of sampling error due to fact that SP was mixture of $\mathrm{SP}^{*}$ with $\mathrm{k}$ of $0.912 \mathrm{~d}^{-1}$ and SV with $\mathrm{k}$ of $0.254 \mathrm{~d}^{-1}$.

Like when MP and CP were varied, also varying $C P$ and SP only ratio 0:1:2 was adequately fitted by both MGM and Cone model with over $99 \%$ of variations explained by the models. Both its hydrolysis rate constant $\mathrm{k}$ and lag phase $\lambda$ were improved to 0.298 $\mathrm{d}^{-1}$ and 0.97 days compared to its parent substrates. Unlike the ratios that were adequately fitted by both MGM and Cone model, ratio 0:1:1 was only adequately fitted by the MGM explaining over $99 \%$ of its variations. This however does not qualify it to be a good ratio for anaerobic stability given that its $\mathrm{pH}_{\text {end }}$ was 5.86 indicating acidification. Ratio 0:2:1 on the other hand was never fitted by any of the three models although it gave one of the highest methane yield of $39 \mathrm{Nm}^{3} \mathrm{CH}_{4} / \mathrm{kg}$ VS. Since no model fitted it, there might have been intermediary build up, leading to acidification evidenced by $\mathrm{pH}_{\text {end }}$ value of 5.9. This suggests that using two parts of CP with one part of SP in anaerobic digestion for biogas production would probably end in an acidic state.

Varying MP, CP and SP, ratios 1:1:1 and 4:1:1 were fitted adequately by both MGM and cone model. On the other hand, ratio 1:1:4 was fitted by the cone model only while ratio 1:4:1 was not fitted by any model. This again is supported by their $\mathrm{pH}_{\text {end }}$ values in Table 3 which show that ratio 1:4:1 exhibited acidic situation compared to the rest. Generally, there was improvement for all ratios in their $\mathrm{k}$ and $\lambda$ values compared to their parent substrates. It can be concluded that both hydrolysis rate constants and lag phase depended on the proportions of substrates in the mixture which is in agreement with Veeken and Hamelers [24] observation.

\subsection{Effect of MP:CP:SP Ratio Variation on Hydraulic Retention Time}

Figure 5 illustrates the effect of MP:CP:SP ratios on hydraulic retention time (HRT). For this study, HRT is taken as the time when over $90 \%$ of the cumulative specific methane yield is attained for any given MP:CP:SP ratio [42]. It is taken as the time when cumulative specific methane production curve for any substrate levels off or reaches its plateau according to Zhang, El-Mashad [43]. Therefore, from Figures 5(a)-(c) it can be 

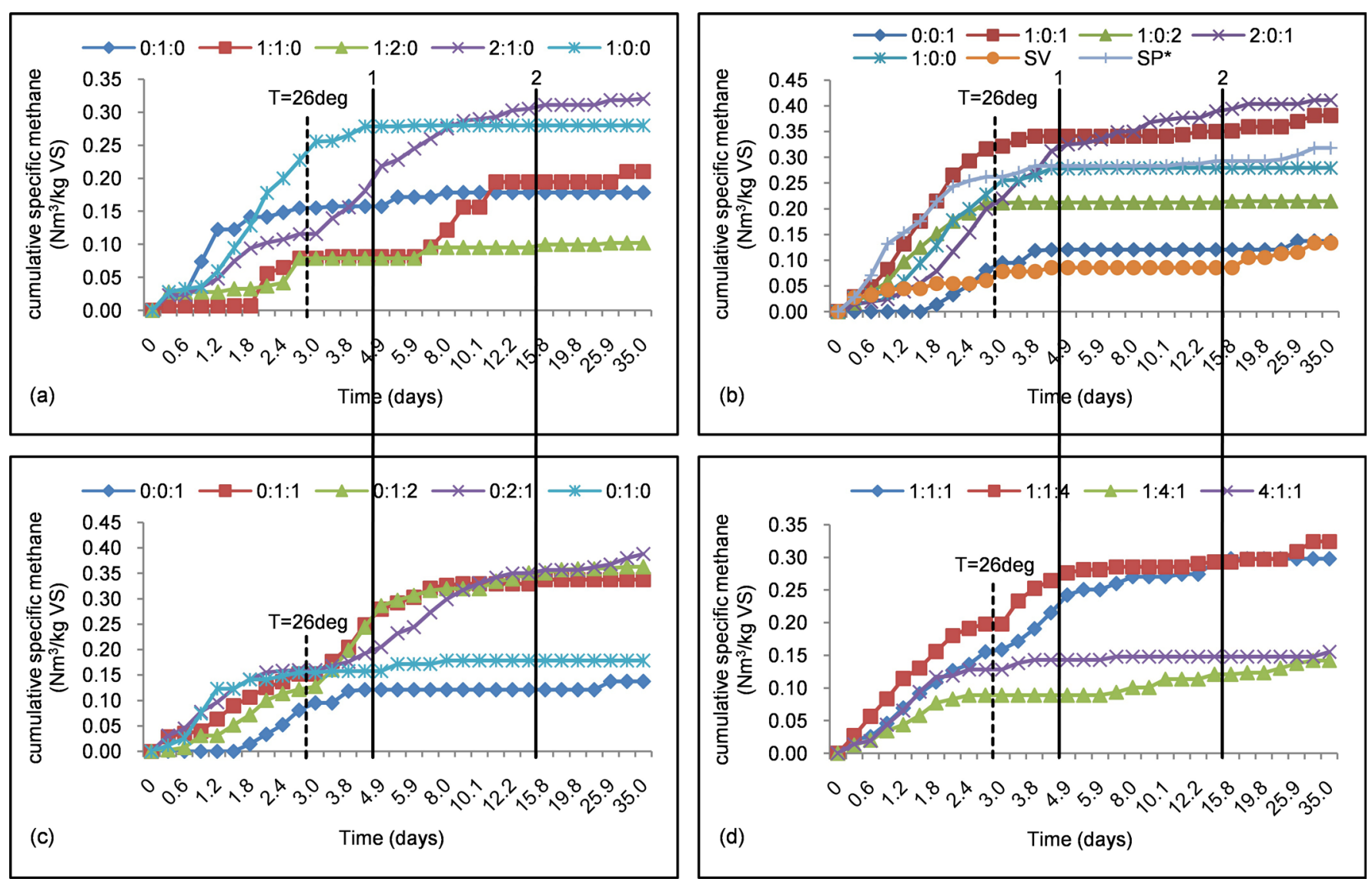

Figure 5. Illustration of temperature effect on digestion process and substrate ratio effect on HRT. NB: Lines 1 and 2 represent HRT for the respective substrate ratios when cumulative specific methane production curves level off. The dotted line $\mathrm{T}=26 \mathrm{deg}$ shows temperature shock effect on methane production process.

seen that the parent substrates (MP, CP, SP and SP*) with the exception of SV had reached over $90 \%$ of their methane yield by day five as indicated by vertical line 1 . This short HRT of less than 5 days is attributed to their fast digestion evidenced by their high hydrolysis rate constants presented in Table 4. Using such substrates with such a short HRT are susceptible to washout of microorganisms which may result into volatile fatty acids build up leading to acidification [8] [26]. Similarly, this short HRT of less than 5 days was exhibited by ratios 1:0:1 and 1:0:2 in Figure 5(b) and ratio 4:1:1 in Figure 5(d). This again is due to the quick digestion of these ratios as supported by their high hydrolysis rate constants of $0.684,0.779$ and $0.798 \mathrm{~d}^{-1}$ respectively.

Nevertheless, co-digestion has shown that HRT for ratio 2:1:0 went up to more than 15 days when MP and CP were varied. When MP and SP were varied, HRT for ratio 2:0:1 also increased to more than 15 days as indicated by vertical line 2 compared to its parent substrates. The same is true for ratios 0:1:1, 0:1:2 and 0:2:1 when CP and SP were varied and ratios 1:1:1 and 1:1:4 when MP, $\mathrm{CP}$ and SP varied. Results reported by Heo, Park [12] also show that when food waste with HRT of less than 5 days was co-digested with waste activated sludge at a ratio of 1:1, HRT reached 13 days for optimum digester performance. 


\subsection{Temperature Effect on Anaerobic Co-Digestion of MP, CP and SP Process Stability}

Figure 6 shows temperature and pressure profiles recorded during the batch digestion experiment of MP:CP:SP ratio variations. Looking at both Figure 5 and Figure 6, Figure 5 shows that between the first day and third day, the cumulative methane curves were generally running smooth when temperature fluctuations in Figure 6 were going below $30^{\circ} \mathrm{C}$ but not reaching to $26^{\circ} \mathrm{C}$ between the same period. Smooth cumulative methane curves are an indication that the rate of biogas production was constant in the stated period even when temperature reached to $27^{\circ} \mathrm{C}$. However, when temperature fluctuations in the incubator reached to $26^{\circ} \mathrm{C}$ after the third day, shown by the "star marker" in Figure 6, there was a setback in the digestion process. This setback is evidenced by the kinks in the cumulative methane curves in Figure 5 at points shown by the dotted lines labeled $\mathrm{T}=26 \mathrm{deg}$ which is as a result of a reduction in biogas production rate. Nevertheless, when the temperature rose again, the curves smoothened for most of the substrate ratios with the exception of ratios 1:1:0 and 1:2:0 in Figure 5(a), implying that microorganisms were able to adjust after temperature shocks. This adjusting of microorganisms after temperature shock was also noted by Chae, Jang [44]. Datta [45], also found that methane production was inhibited by temperature $\leq 25^{\circ} \mathrm{C}$. In addition, the kinks in curves were more pronounced in substrate ratios consisting of CP (Figure 5(a), Figure 5(c), Figure 5(d)) than those where MP and SP were varying (Figure 5(b)). This suggests that temperature could be substrate specific and in this case to $\mathrm{CP}$, given that substrate ratios consisting of cassava peels were more susceptible to instability when temperature dropped to $26^{\circ} \mathrm{C}$. Therefore, there is need to maintain

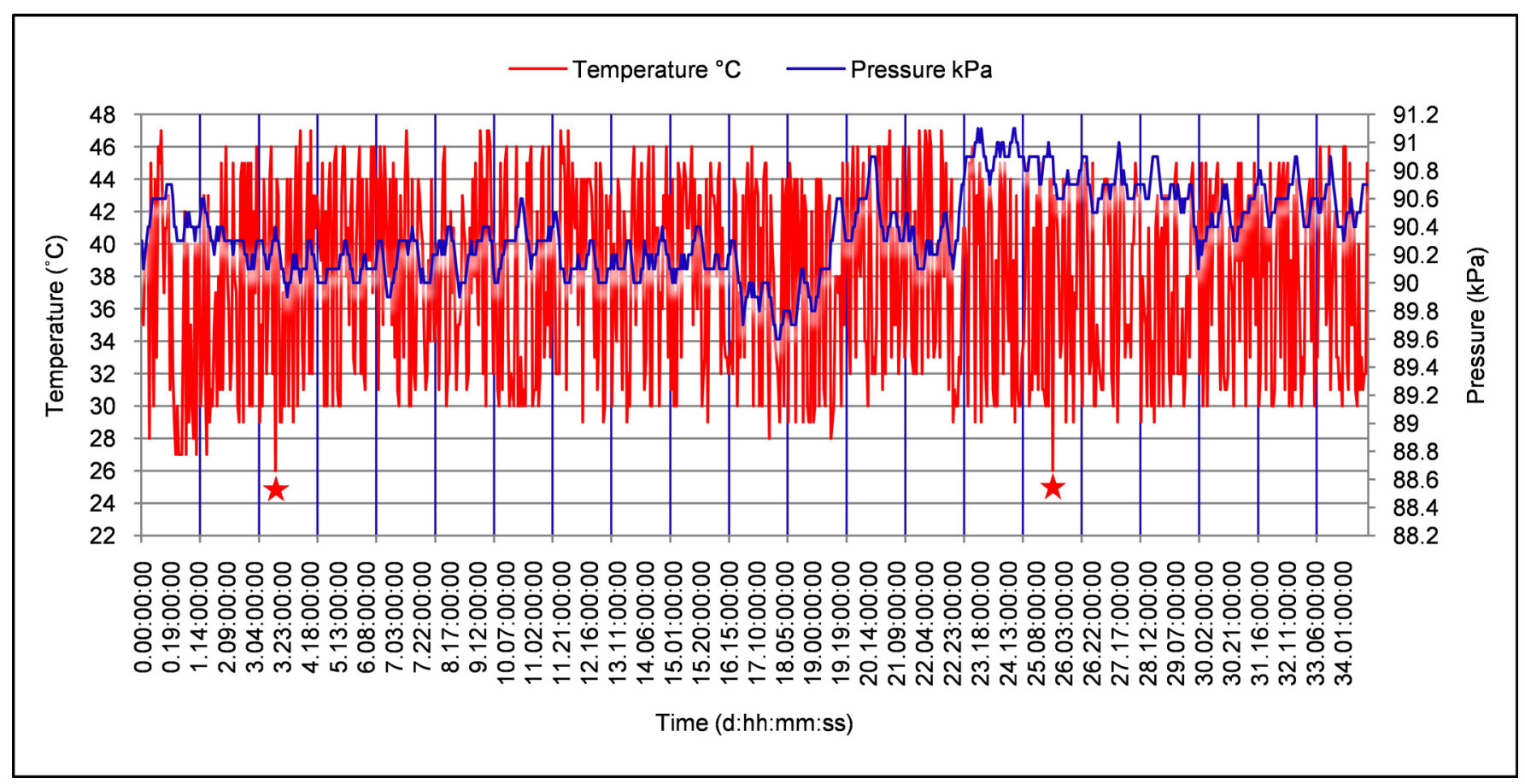

Figure 6. Incubator temperature and ambient pressure changes. 
temperature above $26^{\circ} \mathrm{C}$ for effective anaerobic digestion of substrates consisting $\mathrm{MP}$, $\mathrm{CP}$ and SP, but more particularly $\mathrm{CP}$, though more investigations are needed. Unlike methane yield, kinetic parameters and HRT that showed to be dependent on the proportions of the substrates in the mixtures, temperature effect was not, but specific to a particular substrate in the mixture. Generally, ratios 2:1:0, 2:0:1, 1:0:1, 0:1:1, 0:1:2, 0:2:1 1:1:1 and 1:1:4 were able to with stand temperature shocks, which are almost the same ratios that had a synergetic effect on HRT, kinetics of methane production, $\mathrm{pH}$ and methane yield.

\section{Conclusions}

1) Results from this study have shown that $M P, C P, S P$, and $S P^{\star}$ are digested very fast due to their high rate of hydrolysis compared to SV whose hydrolysis rate is low due to its high content of cellulose. As a result of this fast digestion, they have a short HRT of less than 5 days which may result into washout of microorganisms leading to accumulation of intermediary products that inhibit methanogenesis process.

2) Co-digestion of MP, CP and SP has shown to have synergetic effect on HRT, methane yield and its kinetics (hydrolysis rate constant and lag phase). In addition, HRT, methane yield and its kinetics have shown to be dependent on the proportion of any given parent substrate in a mixture.

3) No single model adequately fitted all the experimental data of methane production from the respective MP:CP:SP ratios. However, MGM and Cone model interchangeably or balanced in fitting the data, though they also depended on the proportions of the parent substrates in the mixtures. The exponential model on the other hand fitted only 1:1:1 ratio.

4) Temperature effect on the digestion process of MP:CP:SP ratios was more pronounced when temperature fluctuated to $26^{\circ} \mathrm{C}$, although microorganisms were able to adjust after this temperature shock.

5) Ratios 2:1:0, 2:0:1, 0:1:1, 0:1:2, 1:1:1 and 1:1:4 were consistent all through in terms of model fitting, having a positive synergetic effect on HRT, hydrolysis rate constant, lag phase and methane yield, withstanding temperature shock and maintaining a relatively favourable $\mathrm{pH}$ for methanogens. Therefore, anyone having at least two of MP, CP and SP has an optimum ratio that favours methane yield and the factors that may affect its production.

6) However, more investigations are needed when using bigger samples as there could have been sampling errors while using small samples for the tested substrates. In addition, ways of how to maintain $\mathrm{pH}$ in the optimum range of $6.6-7.3$ without using the usual $\mathrm{Na}_{2} \mathrm{CO}_{3}$ as a buffering agent is another area for research to enable use of household waste as a potential standalone feedstock for biogas production.

\section{Acknowledgements}

This research was funded by the Office of Research and Development (ORD) University of Botswana and support made possible through a capacity building competitive 
grant Training the next generation of scientists provided by Carnegie Cooperation of New York through the Regional Universities Forum for Capacity Building in Agriculture (RUFORUM). Peter is a METEGA sponsored graduate student at University of Botswana.

\section{References}

[1] Rajendran, K., Aslanzadeh, S. and Taherzadeh, M.J. (2012) Household Biogas Digesters-A Review. Energies, 5, 2911-2942. https://doi.org/10.3390/en5082911

[2] FAOSTAT (2016) Production Crops Africa. Food and Agriculture Organization of the United Nations Statistics Division. http://faostat3.fao.org/2014

[3] Banga, M. (2011) Household Knowledge, Attitudes and Practices in Solid Waste Segregation and Recycling: The Case of Urban Kampala. Zambia Social Science Journal, 2.

[4] Ogwueleka, T.C. (2013) Survey of Household Waste Composition and Quantities in Abuja, Nigeria. Resources, Conservation and Recycling, 77, 52-60.

https://doi.org/10.1016/j.resconrec.2013.05.011

[5] Hanc, A., Novak, P., Dvorak, M., Habart, J. and Svehla, P. (2011) Composition and Parameters of Household Bio-Waste in Four Seasons. Waste Management, 31, 1450-1460. https://doi.org/10.1016/j.wasman.2011.02.016

[6] House, D. (2006) Biogas Handbook. Being a Compendium of the Art and Science of Using Anything Once Alive to Produce a Burnable Gas for Powering Light, Automobiles, Ovens, Tractors, Water Heaters, Furnaces and Various Contraptions. Alternative House Information, USA, 285.

[7] Ward, A.J., Hobbs, P.J., Holliman, P.J. and Jones, D.L. (2008) Optimisation of the Anaerobic Digestion of Agricultural Resources. Bioresource Technology, 99, 7928-7940. https://doi.org/10.1016/j.biortech.2008.02.044

[8] Chynoweth, D.P., Owen, J.M. and Legrand, R. (2001) Renewable Methane from Anaerobic Digestion of Biomass. Renewable Energy, 22, 1-8.

https://doi.org/10.1016/S0960-1481(00)00019-7

[9] El-Mashad, H.M. and Zhang, R. (2010) Biogas Production from Co-Digestion of Dairy Manure and Food Waste. Bioresource Technology, 101, 4021-4028.

https://doi.org/10.1016/j.biortech.2010.01.027

[10] Angelidaki, I. and Ellegaard, L. (2003) Codigestion of Manure and Organic Wastes in Centralized Biogas Plants. Applied Biochemistry and Biotechnology, 109, 95-105. https://doi.org/10.1385/ABAB:109:1-3:95

[11] Ganesh, R., Torrijos, M., Sousbie, P., Steyer, J.P., Lugardon, A. and Delgenes, J.P. (2013) Anaerobic Co-Digestion of Solid Waste: Effect of Increasing Organic Loading Rates and Characterization of the Solubilised Organic Matter. Bioresource Technology, 130, 559-569. https://doi.org/10.1016/j.biortech.2012.12.119

[12] Heo, N.H., Park, S.C. and Kang, H. (2004) Effects of Mixture Ratio and Hydraulic Retention Time on Single-Stage Anaerobic Co-Digestion of Food Waste and Waste Activated Sludge. Journal of Environmental Science and Health, Part A, 39, 1739-1756. https://doi.org/10.1081/ESE-120037874

[13] Liu, X., Gao, X.B., Wang, W., Zheng, L., Zhou, Y.J. and Sun, Y.F. (2012) Pilot-Scale Anaerobic Co-Digestion of Municipal Biomass Waste: Focusing on Biogas Production and GHG Reduction. Renewable Energy, 44, 463-468.

https://doi.org/10.1016/j.renene.2012.01.092 
[14] Pitt, R.E., Cross, T.L., Pell, A.N., Schofield, P. and Doane, P.H. (1999) Use of in Vitro Gas Production Models in Ruminal Kinetics. Mathematical Biosciences, 159, 145-163. https://doi.org/10.1016/S0025-5564(99)00020-6

[15] Sluiter, A., et al. (2008) Determination of Structural Carbohydrates and Lignin in Biomass. Laboratory Analytical Procedure.

[16] Mussoline, W.A. and Wilkie, A.C. (2015) Anaerobic Digestion Potential of Coproducts Associated with Ethanol Production from Sweetpotato: A Review. Industrial Biotechnology, 11, 113-126. https://doi.org/10.1089/ind.2014.0027

[17] APHA (2005) Standard Methods for the Examination of Water and Wastewaste. In American Public Health Association, American Water Works Association, Water Environment Federation. APHA, Washington DC.

[18] Nielfa, A., Cano, R. and Fdz-Polanco, M. (2015) Theoretical Methane Production Generated by the Co-Digestion of Organic Fraction Municipal Solid Waste and Biological Sludge. Biotechnology Reports, 5, 14-21. https://doi.org/10.1016/j.btre.2014.10.005

[19] AOAC (2006) Association of Official Analytical Chemists International.

[20] Lay, J.-J., Li, Y.-Y. and Noike, T. (1997) Influences of $\mathrm{pH}$ and Moisture Content on the Methane Production in High-Solids Sludge Digestion. Water Research, 31, 1518-1524. https://doi.org/10.1016/S0043-1354(96)00413-7

[21] Walker, M., Zhang, Y., Heaven, S. and Banks, C. (2009) Potential Errors in the Quantitative Evaluation of Biogas Production in Anaerobic Digestion Processes. Bioresource Technology, 100, 6339-6346. https://doi.org/10.1016/j.biortech.2009.07.018

[22] El-Mashad, H.M. (2013) Kinetics of Methane Production from the Codigestion of Switchgrass and Spirulina platensis Algae. Bioresource Technology, 132, 305-312. https://doi.org/10.1016/j.biortech.2012.12.183

[23] VDI-4630 (2006) Fermentation of Organic Materials: Characterisation of the Substrate, Sampling, Collection of Material Data, Fermentation Tests. Verlag des Vereins Deutscher Ingenieure, Düsseldorf, 92.

[24] Veeken, A. and Hamelers, B. (1999) Effect of Temperature on Hydrolysis Rates of Selected Biowaste Components. Bioresource Technology, 69, 249-254. https://doi.org/10.1016/S0960-8524(98)00188-6

[25] Donoso-Bravo, A., Pérez-Elvira, S. and Fdz-Polanco, F. (2010) Application of Simplified Models for Anaerobic Biodegradability Tests. Evaluation of Pre-Treatment Processes. Chemical Engineering Journal, 160, 607-614. https://doi.org/10.1016/j.cej.2010.03.082

[26] Clarke, W.P., Radnidge, P., Lai, T.E., Jensen, P.D. and Hardin, M.T. (2008) Digestion of Waste Bananas to Generate Energy in Australia. Waste Management, 28, 527-533. https://doi.org/10.1016/j.wasman.2007.01.012

[27] Appels, L., Baeyens, J., Degrève, J. and Dewil, R. (2008) Principles and Potential of the Anaerobic Digestion of Waste-Activated Sludge. Progress in Energy and Combustion Science, 34, 755-781. https://doi.org/10.1016/j.pecs.2008.06.002

[28] Santosh, Y., Sreekrishnan, T.R., Kohli, S. and Rana, V. (2004) Enhancement of Biogas Production from Solid Substrates Using Different Techniques-A Review. Bioresource Technology, 95, 1-10. https://doi.org/10.1016/j.biortech.2004.02.010

[29] Anhwange, B., Ugye, T. and Nyiaatagher, T. (2008) Chemical Composition of Musa sapientum (Banana) Peels. Journal of Food Technology, 6, 263-266.

[30] Emaga, T. H., Andrianaivo, R.H., Wathelet, B., Tchango, J.T. and Paquot, M. (2007) Effects of the Stage of Maturation and Varieties on the Chemical Composition of Banana and Plantain Peels. Food Chemistry, 103, 590-600. 
https://doi.org/10.1016/j.foodchem.2006.09.006

[31] Oboh, G. (2006) Nutrient Enrichment of Cassava Peels Using a Mixed Culture of Saccharomyces cerevisae and Lactobacillus spp Solid Media Fermentation Techniques. Electronic Journal of Biotechnology, 9.

[32] Ofoefule, A. and Uzodinma, E. (2009) Biogas Production from Blends of Cassava (Manihot utilissima) Peels with Some Animal Wastes. International Journal of Physical Sciences, 4, 398-402.

[33] Tumutegyereize, P., Muranga, F., Kawongolo, J. and Nabugoomu, F. (2011) Optimization of Biogas Production from Banana Peels: Effect of Particle Size on Methane Yield. African Journal of Biotechnology, 10, 18243-18251. https://doi.org/10.5897/AJB11.2442

[34] Gunaseelan, V.N. (2004) Biochemical Methane Potential of Fruits and Vegetable Solid Waste Feedstocks. Biomass and Bioenergy, 26, 389-399. https://doi.org/10.1016/j.biombioe.2003.08.006

[35] Khan, M.T., Brulé, M., Maurer, C., Argyropoulos, D., Müller, J. and Oechsner, H. (2016) Batch Anaerobic Digestion of Banana Waste-Energy Potential and Modelling of Methane Production Kinetics. Agricultural Engineering International: CIGR Journal, 18, 110-128.

[36] Jekayinfa, S. and Scholz, V. (2013) Laboratory Scale Preparation of Biogas from Cassava Tubers, Cassava Peels, and Palm Kernel Oil Residues. Energy Sources, Part A: Recovery, Utilization, and Environmental Effects, 35, 2022-2032. https://doi.org/10.1080/15567036.2010.532190

[37] Bardiya, N., Somayaji, D. and Khanna, S. (1996) Biomethanation of Banana Peel and Pineapple Waste. Bioresource Technology, 58, 73-76. https://doi.org/10.1016/S0960-8524(96)00107-1

[38] Panichnumsin, P., Nopharatana, A., Ahring, B. and Chaiprasert, P. (2010) Production of Methane by Co-Digestion of Cassava Pulp with Various Concentrations of Pig Manure. Biomass and Bioenergy, 34, 1117-1124. https://doi.org/10.1016/j.biombioe.2010.02.018

[39] Li, Y., Zhang, R., Chen, C., Liu, G., He, Y. and Liu, X. (2013) Biogas Production from Co-Digestion of Corn Stover and Chicken Manure under Anaerobic Wet, Hemi-Solid, and Solid State Conditions. Bioresource Technology, 149, 406-412. https://doi.org/10.1016/j.biortech.2013.09.091

[40] Lin, J., Zuo, J., Gan, L., Li, P., Liu, F., Wang, K., et al. (2011) Effects of Mixture Ratio on Anaerobic Co-Digestion with Fruit and Vegetable Waste and Food Waste of China. Journal of Environmental Sciences, 23, 1403-1408. https://doi.org/10.1016/S1001-0742(10)60572-4

[41] Mata-Alvarez, J., Macé, S. and Llabrés, P. (2000) Anaerobic Digestion of Organic Solid Wastes. An Overview of Research Achievements and Perspectives. Bioresource Technology, 74, 3-16. https://doi.org/10.1016/S0960-8524(00)00023-7

[42] Pang, Y., Liu, Y., Li, X., Wang, K. and Yuan, H. (2008) Improving Biodegradability and Biogas Production of Corn Stover through Sodium Hydroxide Solid State Pretreatment. Energy Fuels, 22, 2761-2766. https://doi.org/10.1021/ef800001n

[43] Zhang, R., El-Mashad, H.M., Hartman, K., Wang, F., Liu, G., Choate, C., et al. (2007) Characterization of Food Waste as Feedstock for Anaerobic Digestion. Bioresource Technology, 98, 929-935. https://doi.org/10.1016/j.biortech.2006.02.039

[44] Chae, K.J., Jang, A., Yim, S.K. and Kim, I.S. (2008) The Effects of Digestion Temperature and Temperature Shock on the Biogas Yields from the Mesophilic Anaerobic Digestion of Swine Manure. Bioresource Technology, 99, 1-6. https://doi.org/10.1016/j.biortech.2006.11.063

[45] Datta, R. (1981) Acidogenic Fermentation of Corn Stover. Biotechnology and Bioengineering, 23, 61-77. https://doi.org/10.1002/bit.260230106 
Submit or recommend next manuscript to SCIRP and we will provide best service for you:

Accepting pre-submission inquiries through Email, Facebook, LinkedIn, Twitter, etc. A wide selection of journals (inclusive of 9 subjects, more than 200 journals)

Providing 24-hour high-quality service

User-friendly online submission system

Fair and swift peer-review system

Efficient typesetting and proofreading procedure

Display of the result of downloads and visits, as well as the number of cited articles

Maximum dissemination of your research work

Submit your manuscript at: http://papersubmission.scirp.org/

Or contact jsbs@scirp.org 